\title{
Recent Payment Trends in the United States
}

Geoffrey R. Gerdes, of the Board's Division of Reserve Bank Operations and Payment Systems, prepared this article, with assistance from Kathy $C$. Wang.

Survey data collected for the Federal Reserve in 2007 show a continuation of significant changes in the way consumers and businesses make payments. Data previously published by the Federal Reserve show that in 2003 the number of electronic payments in the United States (made mostly through debit and credit card networks and the automated clearinghouse system) exceeded the number of check payments for the first time. ${ }^{1}$ The recent data indicate that by 2006 the number of electronic payments was more than twice the number of check payments, or about two-thirds of all noncash payments (table 1, chart 1). The value of electronic payments has also grown substantially, but in 2006 they still accounted for less than half the value of noncash payments ( 45 percent). ${ }^{2}$

The use of checks has been declining since the mid-1990s, generally because check payments-and most likely some cash payments_-are being replaced by payments made with electronic instruments. The latest data show a continuation of this trend. Consumers in particular are paying electronically much more often than in the past, with most of the increase between 2003 and 2006 due to a rapid rise in the

NotE: Darrel W. Parke and May X. Liu, of the Board's Division of Research and Statistics, provided valuable assistance with survey design, sampling, and production of the statistical estimates.

1. Previous reports include Geoffrey R. Gerdes, Jack K. Walton II, May X. Liu, and Darrel W. Parke (2005), "Trends in the Use of Payment Instruments in the United States," Federal Reserve Bulletin, vol. 91 (Spring), pp. 180-201, www.federalreserve.gov/pubs/bulletin/ 2005/spring05_payment.pdf; and Geoffrey R. Gerdes and Jack K. Walton II (2002), "The Use of Checks and Other Noncash Payment Instruments in the United States," Federal Reserve Bulletin, vol. 88 (August), pp. 360-74, www.federalreserve.gov/pubs/bulletin/2002/ 0802_2nd.pdf.

2. Payments transmitted over large-value funds transfer systems (such as Fedwire, operated by the Federal Reserve, and the Clearing House Interbank Payments System, or CHIPS, operated by the Clearing House Payments Company), sometimes called wholesale payments, are outside the scope of this article. These systems are used primarily for large monetary and financial transactions, such as overnight loans between depository institutions. Including such transactions in the calculations reported in this article would not meaningfully affect the total number of payments but would dramatically increase the value. An unknown number of transactions of other types are made over these systems by consumers and businesses. number of debit card payments of relatively low value (on average, \$39). Consumers' checks are also increasingly being "converted" into electronic payments made via the automated clearinghouse $(\mathrm{ACH})$ system. ${ }^{3}$ In 2006, about 8 percent of all checks written were converted to $\mathrm{ACH}$ payments, compared with fewer than 1 percent in 2003.

The interbank check-clearing system itself is also rapidly becoming more electronic, as original paper checks are increasingly being "truncated" and replaced with electronic images during the checkclearing process. ${ }^{4}$ The apparent catalyst for the dramatic change in check clearing was passage of the Check Clearing for the 21st Century Act (Check 21). Signed into law in October 2003 and taking effect in October 2004, Check 21 allows a collecting bank to present a legally equivalent paper copy of an original check — called a "substitute check" —if the paying bank requires a check to be presented for payment in paper form..$^{5}$ In early 2007 , an estimated 57 percent of all interbank checks in the United States were presented in original paper form and about 43 percent were truncated and ultimately presented to the paying bank either electronically or as a substitute check. Of the portion that were truncated, 66 percent were presented electronically. The number of checks presented electronically in 2007 was approximately three times the number presented electronically just one year earlier. More recent data on the portion of interbank checks presented by the Federal Reserve Banks indicate that dramatic changes have continued since the 2007 surveys. Data for June 2008, for example, indicate that about 53 percent of checks

3. Most check conversions take place at "lockboxes" to which bill payments are mailed; a small proportion take place at retail establishments when checks are tendered at the point of sale. Consumers whose checks are going to be converted are permitted to "opt out." Under the rules of the National Automated Clearinghouse Association (NACHA), corporate and business-format checks are not eligible for conversion to $\mathrm{ACH}$ payments.

4. Interbank checks are checks that pass between depository institutions.

5. Before Check 21, paying banks' requirement that the original check be presented was a major barrier to the widespread use of electronic check-clearing technology. The option of providing a substitute check gives depository institutions and their agents the freedom to use electronic check-processing methods for most or all of a check's journey to the paying bank, as the substitute check is needed only at the end of the process if the paying bank requires paper. 
1. Noncash payments in the United States, by type of payment, 2003 and 2006

\begin{tabular}{|c|c|c|c|c|c|c|c|c|}
\hline \multirow{3}{*}{ Type of payment } & \multirow{2}{*}{\multicolumn{2}{|c|}{ Number }} & \multicolumn{6}{|c|}{ Value } \\
\hline & & & \multicolumn{3}{|c|}{ Nominal } & \multicolumn{3}{|c|}{ Constant 2006 dollars } \\
\hline & $\begin{array}{l}\text { Billions of } \\
\text { payments }\end{array}$ & $\begin{array}{l}\text { Percent } \\
\text { of total }\end{array}$ & $\begin{array}{l}\text { Trillions of } \\
\text { dollars }\end{array}$ & $\begin{array}{l}\text { Percent } \\
\text { of total }\end{array}$ & $\begin{array}{l}\text { Average, in } \\
\text { dollars }\end{array}$ & $\begin{array}{c}\text { Trillions of } \\
\text { dollars }\end{array}$ & $\begin{array}{l}\text { Percent } \\
\text { of total }\end{array}$ & $\begin{array}{l}\text { Average, } \\
\text { in dollars }\end{array}$ \\
\hline \multicolumn{9}{|l|}{2003} \\
\hline Check $^{1} \ldots$ & 37.3 & 45.8 & 41.1 & 60.9 & 1,103 & 45.1 & 60.9 & 1,209 \\
\hline Electronic & 44.1 & 54.2 & 26.5 & 39.1 & 599 & 29.0 & 39.1 & 656 \\
\hline Debit card & 15.6 & 19.2 & .6 & .9 & 40 & .7 & .9 & 44 \\
\hline Signature & 10.3 & 12.6 & .4 & 6 & 42 & .5 & 6 & 46 \\
\hline PIN ..... & 5.3 & 6.6 & .2 & .3 & 38 & .2 & .3 & 42 \\
\hline Credit card & 19.0 & 23.3 & 1.7 & 2.5 & 89 & 1.9 & 2.5 & 98 \\
\hline General-purpose $\mathrm{e}^{2}$ & 15.2 & 18.7 & 1.4 & 2.1 & 93 & 1.5 & 2.1 & 102 \\
\hline Private-label $^{3} \ldots$ & 3.8 & 4.6 & .3 & .4 & 76 & .3 & .4 & 83 \\
\hline $\mathrm{ACH}^{4} \ldots \ldots \ldots$ & 8.8 & 10.7 & 24.1 & 35.7 & 2,754 & 26.4 & 35.7 & 3,017 \\
\hline Retail & 7.3 & 9.0 & 8.1 & 12.0 & 1,106 & 8.9 & 12.0 & 1,211 \\
\hline CCD. & 1.4 & 1.7 & 16.0 & 23.7 & 11,272 & 17.5 & 23.7 & 12,348 \\
\hline $\mathrm{EBT}^{5}$. & .8 & 1.0 & $*$ & $*$ & 26 & $*$ & $*$ & 29 \\
\hline Total noncash payments & 81.4 & 100.0 & 67.6 & 100.0 & 830 & 74.1 & 100.0 & 909 \\
\hline \multicolumn{9}{|l|}{ МЕмо } \\
\hline Total checks written ${ }^{6}$ & 37.6 & 46.2 & 41.2 & 61.0 & 1,095 & 45.1 & 61.0 & 1,200 \\
\hline Checks converted to $\mathrm{ACH}$ & .3 & .4 & .1 & .1 & 187 & .1 & .1 & 205 \\
\hline \multicolumn{9}{|l|}{2006} \\
\hline Check $^{1}$. & 30.5 & 32.7 & 41.6 & 54.9 & 1,363 & 41.6 & 54.9 & 1,363 \\
\hline Electronic & 62.8 & 67.3 & 34.2 & 45.1 & 544 & 34.2 & 45.1 & 544 \\
\hline Debit card & 25.3 & 27.1 & 1.0 & 1.3 & 39 & 1.0 & 1.3 & 39 \\
\hline Signature $\ldots \ldots \ldots$ & 16.0 & 17.1 & .6 & .8 & 40 & .6 & .8 & 40 \\
\hline PIN ...... & 9.4 & 10.0 & .3 & .5 & 37 & .3 & .5 & 37 \\
\hline Credit card & 21.7 & 23.3 & 2.1 & 2.8 & 98 & 2.1 & 2.8 & 98 \\
\hline General-purpose $^{2}$ & 19.0 & 20.3 & 1.9 & 2.5 & 99 & 1.9 & 2.5 & 99 \\
\hline Private-label $^{3} \ldots$. . & 2.8 & 3.0 & .3 & .3 & 92 & .3 & .3 & 92 \\
\hline $\mathrm{ACH}^{4} \ldots \ldots \ldots$ & 14.6 & 15.7 & 31.0 & 40.9 & 2,121 & 31.0 & 40.9 & 2,121 \\
\hline Retail & 12.6 & 13.5 & 12.1 & 16.0 & 959 & 12.1 & 16.0 & 959 \\
\hline CCD . & 2.0 & 2.2 & 18.9 & 25.0 & 9,384 & 18.9 & 25.0 & 9,384 \\
\hline $\mathrm{EBT}^{5} \ldots$ & 1.1 & 1.2 & $*$ & $*$ & 27 & $*$ & $*$ & 27 \\
\hline Total noncash payments & 93.3 & 100.0 & 75.8 & 100.0 & 812 & 75.8 & 100.0 & 812 \\
\hline \multirow{6}{*}{$\begin{array}{l}\text { MEMo } \\
\text { Total checks written }{ }^{6} \ldots \ldots \ldots \\
\text { Checks converted to ACH .. }\end{array}$} & & & & & & & & \\
\hline & 33.1 & 35.5 & 42.3 & 55.8 & 1,277 & 42.3 & 55.8 & 1,277 \\
\hline & 2.6 & 2.8 & .7 & .9 & 267 & .7 & .9 & 267 \\
\hline & \multirow{2}{*}{\multicolumn{2}{|c|}{ Number }} & \multicolumn{6}{|c|}{ Value } \\
\hline & & & \multicolumn{3}{|c|}{ Nominal } & \multicolumn{3}{|c|}{ Constant 2006 dollars } \\
\hline & $\begin{array}{l}\text { Change } \\
\text { over period } \\
\text { (billions of } \\
\text { payments) }\end{array}$ & $\begin{array}{l}\text { Annual } \\
\text { rate of } \\
\text { change } \\
\text { (percent) }\end{array}$ & $\begin{array}{l}\text { Change } \\
\text { over period } \\
\text { (trillions of } \\
\text { dollars) }\end{array}$ & $\begin{array}{l}\text { Annual } \\
\text { rate of } \\
\text { change } \\
\text { (percent) }\end{array}$ & $\begin{array}{l}\text { Change } \\
\text { in average } \\
\text { over period } \\
\text { (dollars) }\end{array}$ & $\begin{array}{l}\text { Change } \\
\text { over period } \\
\text { (trillions of } \\
\text { dollars) }\end{array}$ & $\begin{array}{l}\text { Annual } \\
\text { rate of } \\
\text { change } \\
\text { (percent) }\end{array}$ & $\begin{array}{l}\text { Change } \\
\text { in average } \\
\text { over period } \\
\text { (dollars) }\end{array}$ \\
\hline \multicolumn{9}{|l|}{ Change, 2003 to 2006} \\
\hline Check $\ldots \ldots \ldots \ldots \ldots$ & -6.8 & -6.5 & .5 & .4 & 259 & -3.5 & -2.6 & 154 \\
\hline Electronic ... & 18.6 & 12.5 & 7.7 & 8.9 & -55 & 5.2 & 5.6 & -112 \\
\hline Debit card & 9.7 & 17.5 & .4 & 16.0 & -2 & .3 & 12.6 & -5 \\
\hline Signature & 5.7 & 15.8 & .2 & 14.3 & -2 & .2 & 10.9 & -6 \\
\hline PIN ..... & 4.0 & 20.6 & .1 & 19.5 & -1 & .1 & 15.9 & -5 \\
\hline Credit card & 2.8 & 4.6 & .4 & 7.8 & 8 & .3 & 4.6 & $*$ \\
\hline General-purpose & 3.7 & 7.6 & .5 & 9.9 & 6 & .3 & 6.6 & -3 \\
\hline Private-label ............ & -1.0 & -9.6 & * & -3.7 & 16 & -.1 & -6.6 & 9 \\
\hline $\mathrm{ACH} \ldots \ldots \ldots \ldots \ldots$ & 5.9 & 18.7 & 6.9 & 8.8 & -633 & 4.6 & 5.5 & -896 \\
\hline Retail ................ & 5.3 & 19.8 & 4.0 & 14.3 & -147 & 3.2 & 10.8 & -252 \\
\hline $\mathrm{CCD} \ldots \ldots \ldots \ldots \ldots$ & .6 & 12.4 & 2.9 & 5.8 & $-1,888$ & 1.4 & 2.6 & $-2,964$ \\
\hline EBT $\ldots$. & .3 & 10.0 & * & 11.1 & 1 & $*$ & 7.8 & -2 \\
\hline Total noncash payments . & 11.9 & 4.6 & 8.2 & 3.9 & -18 & 1.7 & .8 & -97 \\
\hline \multicolumn{9}{|l|}{ Мемо } \\
\hline Total checks written & -4.5 & -4.1 & 1.1 & .9 & 181 & -2.8 & -2.1 & 77 \\
\hline Checks converted to $\mathrm{ACH}$ & 2.3 & 98.7 & 6 & 123.7 & 80 & .6 & 117.0 & 62 \\
\hline
\end{tabular}

NoTE: The number and value of checks and ACH payments for 2003 are revised from figures reported in Gerdes and Walton, "Trends in the Use of Payment Instruments in the United States," because of revisions to some banks' reported data and because an adjustment was made to account for rapidly changing $\mathrm{ACH}$ check conversion rates. The number and value of checks and $\mathrm{ACH}$ payments for 2006 are revised from figures reported in Federal Reserve System, "The 2007 Federal Reserve Payments Study." Components may not sum to totals and may not yield percentages shown because of rounding.

1. Checks paid, that is, checks that were on-us (involving only one depository institution) and checks processed through the interbank check-clearing system, including original paper checks and truncated checks presented either electronically or as paper substitute checks. Includes checks paid by depository institutions, U.S. Treasury checks, and U.S. Postal Service money orders.
2. Includes four widely accepted credit and charge card networks.

3. Includes private-label credit cards issued by oil companies and many large retailers.

4. Retail ACH payments include payroll, bill payments, and some payments associated with the retail sector of the economy. CCDs are cash concentration or disbursement transactions, about half of which are most likely internal corporate transfers. Retail includes all other $\mathrm{ACH}$ payments.

5. Electronic benefits transfer.

6. Total checks written includes checks paid through the check-clearing system and checks converted to ACH payments.

7. Compound annual growth rate.

* In absolute value, less than 0.05 . 
1. Noncash payments in the United States, selected years

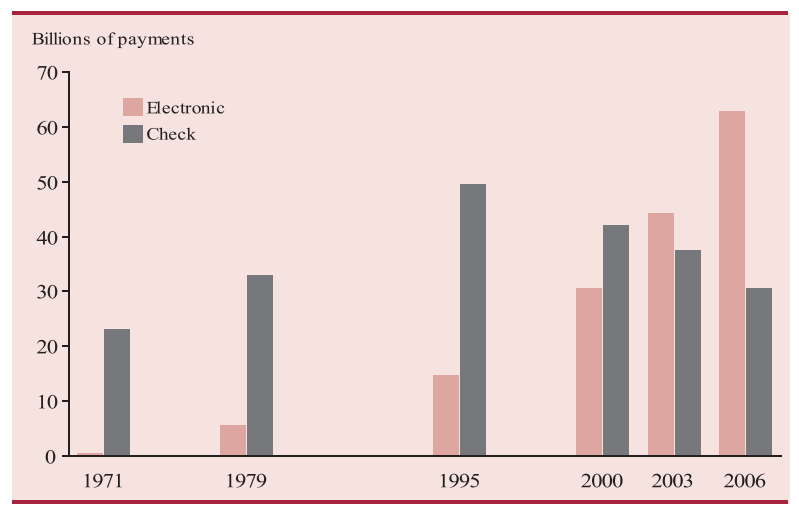

NoTE: Check payments are checks paid, that is, checks that were on-us (involving only one depository institution) and checks processed through the interbank check-clearing system, including original paper checks and truncated checks presented either electronically or as paper substitute checks. Includes checks paid by depository institutions, U.S. Treasury checks, and U.S. Postal Service money orders. Checks converted to $\mathrm{ACH}$ payments are included in electronic payments.

SourCES: The 1971 check figure is from a survey conducted for the Federal Deposit Insurance Corporation and reported in William R. Powers (1976), "A Survey of Bank Check Volumes," Journal of Bank Research (Winter); for all other years, Federal Reserve Board data.

presented to depository institutions through the Reserve Banks were presented electronically, compared with about 30 percent in early 2007.6

This article examines findings from two surveys on the use of noncash payment instruments in the United States conducted for the Federal Reserve-one of depository institutions (the 2007 depository institution survey) and the other of electronic payment networks, processors, and credit card issuers (the 2007 electronic payment survey). Analyses of change in recent years draw on similar surveys conducted in 2004 and 2001. The article also draws on a 2006 Board of Governors survey of checks paid by depository institutions. Information about the surveys is given in the appendix.

\section{TRENDS IN NONCASH PAYMENTS}

The total number of noncash payments in the United States (payments by check, ACH, debit and credit card, and electronic benefits transfer, or EBT) increased from 81 billion to 93 billion between 2003 and 2006 , or 4.6 percent a year. The nominal value of noncash payments increased from $\$ 68$ trillion to $\$ 76$ trillion, or 3.9 percent a year, over the same period. Restating values in constant 2006 dollars, thereby taking into account price inflation averaging 3.1 percent a year over the period, shows that the constant-dollar, or "real," value of noncash payments increased only modestly between 2003 and 2006,

6. The Reserve Banks are estimated to have processed just over 40 percent of all interbank checks in early 2007.
2. Noncash payments per capita in the United States, selected years

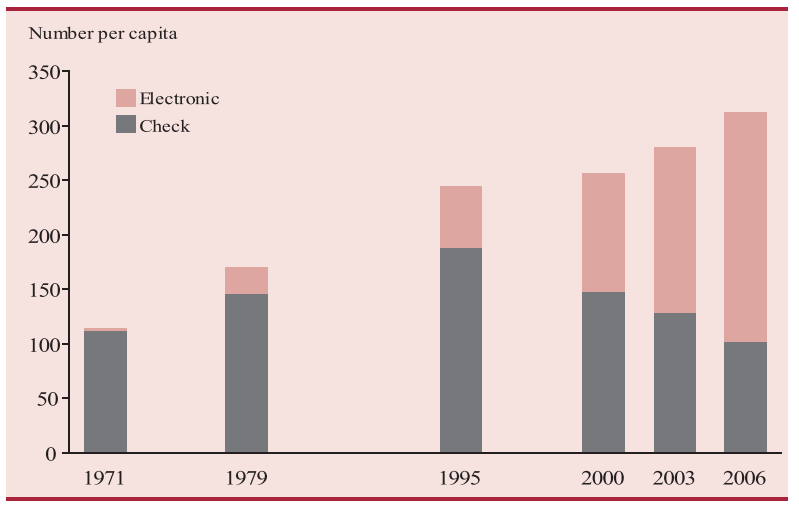

NoTE: Check payments are checks paid, that is, checks that were on-us (involving only one depository institution) and checks processed through the interbank check-clearing system, including original paper checks and truncated checks presented either electronically or as paper substitute checks. Includes checks paid by depository institutions, U.S. Treasury checks, and U.S. Postal Service money orders. Checks converted to ACH payments are included in electronic payments.

SOURCES: The 1971 check figure is from a survey conducted for the Federal Deposit Insurance Corporation and reported in William R. Powers (1976), "A Survey of Bank Check Volumes," Journal of Bank Research (Winter); for all other years, Federal Reserve Board data.

about 0.8 percent a year. ${ }^{7}$ With the number of noncash payments rising faster than the aggregate value, the constant-dollar average value of a payment declined $\$ 97$ over the period (3.7 percent a year), compared with a decline of $\$ 56$ between 2000 and 2003. These trends indicate that much of the growth in the number of noncash payments was due to a large increase in the number of smaller-value noncash payments.

Driven by various socioeconomic factors, the annual number of noncash payments per capita has more than doubled since the 1970s, rising from fewer than 150 in 1971 to more than 300 in 2006 (chart 2). Rising average wealth and income has allowed more consumption, which has evidently led to a rising number of payments for products and services that in the past households either provided for themselves or did without. Some of the increase in the number of noncash payments per capita most likely also came from the replacement of cash with noncash instruments, as many small-value payments once made in cash were increasingly being made via checks, or debit or credit cards. (There is, however, no direct evidence to show whether cash payments themselves increased or decreased overall.)

Growth in noncash payments may also be partly explained by changing payment processing methods themselves. In some cases, replacing a check with an electronic payment increases the number of transac-

7. Adjustments for inflation were made using the implicit price deflator for U.S. gross domestic product. In this article, amounts not identified as constant dollars are nominal amounts, meaning that they are reported in actual dollars and have not been adjusted for inflation. 
tions needed to support a single payment. For example, paying a bill online through a bank sometimes results in two $\mathrm{ACH}$ transactions (in contrast to only one check payment in the past)—one to move the funds from the payer's bank account to a service provider's general payment account, and another to move the funds from the general payment account to the biller's account. Likewise, processing practices that in the past might have involved consolidation of several payments into one check (a practice called "check and list") are in some cases being replaced by practices that generate individual $\mathrm{ACH}$ payments. While changes in processing methods undoubtedly play a role in the growth of noncash payments, the extent of such changes has not been measured.

\section{Check Payments}

The number of checks is declining both because fewer are being written and because some are being converted into electronic payments largely processed through the ACH system. ${ }^{8}$ Because of a rise in check conversions, the number of checks being paid is falling faster than the number of checks being written. Tracking only paid checks, therefore, does not provide a complete picture of how checks are being used. Thus, this article reviews data on two types of checks:

- Checks paid-Checks that are "on us" (those involving only one depository institution) and checks processed through the interbank check-clearing system, including original paper checks and truncated checks (those replaced with electronic images) presented either electronically or as paper substitute checks.

- Checks converted to electronic payments-Checks not processed through the check-clearing system but converted to electronic payments made via the $\mathrm{ACH}$. These items are $\mathrm{ACH}$ payments and do not have or retain any legal status as checks. Instead, the original paper check that was converted is considered a "source document" for the ACH payment it generated.

For purposes of analysis, the aggregation of these two types of checks-paid checks and converted checks-is termed checks written. ${ }^{9}$

8. A small but unknown proportion of checks may also be being converted into electronic payments processed over debit card networks.

9. Although counted as "checks written," converted checks are not necessarily written in a literal sense, but may merely be "tendered," or offered in payment at the point of sale. A customer may fill in the

\section{Checks Paid}

The total number of checks paid in the United States declined from an estimated 37.3 billion in 2003 to 30.5 billion in 2006, a decline of 6.5 percent a year compared with an estimated decline of 3.8 percent a year from 2000 to 2003 (table 1). ${ }^{10}$ The increase in the rate of decline can be explained by the rapid rise in the conversion of check payments into (electronic) $\mathrm{ACH}$ payments. After decades of being the dominant noncash payment type, by 2006 checks paid amounted to only one-third of all noncash payments (chart 1).

In 1971, approximately 112 consumer, business, and government checks were paid per capita in the United States (chart 2). At that time, cash was also used extensively to pay bills and to make other everyday payments, and the use of electronic payments was negligible by comparison. In subsequent years, the number of checks paid per capita rose, reaching 188 in 1995, with some checks replacing cash as a means of payment. The number of electronic payments per capita also grew, but it was still low relative to checks. After the mid-1990s, several factors - the buildup of infrastructure for credit and debit card payments, the expanding issuance of cards, and the increasing use of the ACH to make payroll and bill payments - combined to reduce the use of checks, and by 2006 the annual number of checks paid per capita had fallen to 102 , which was 91 percent of the figure for 1971 and 54 percent of the figure for $1995 .{ }^{11}$

Even as the number of checks paid was declining, the nominal value of checks paid was increasing, from \$41.1 trillion in 2003 to \$41.6 trillion in 2006. In constant 2006 dollars, however, the value was decreasing — by 2.6 percent a year from 2003 to 2006, compared with a decrease of just 1.0 percent a year from 2000 to 2003. Because the number of checks paid was declining at a faster rate than the value, the average constant-dollar value of a check increased $\$ 154$ over the latter period, reaching \$1,363 in 2006. As discussed below, the increase in average value would not have been so great had the growth in

check or may simply hand a blank check to a cashier, who scans the information imprinted on the check, voids the check, and returns it to the customer.

10. The 2003 estimate (earlier reported as 36.6 billion) and the 2000 to 2003 rate of decline are restatements of figures reported in Gerdes and others, "Trends in the Use of Payment Instruments." The restatements are discussed in the appendix.

11. The number of checks per capita has declined not only in the United States, but also in other countries. See the box "Payments in Other Countries." 


\section{Payments in Other Countries}

A comparison with selected industrialized economiesJapan, the European Monetary Union (EMU), the United Kingdom, and Canada-helps put the use of noncash payments in the United States in perspective. The number of checks per capita declined from 2000 to 2006 in all five economies (chart). ${ }^{1}$

Only in the United States, however, was there an accelerating decline in terms of both annual growth rate-a decline of 7.4 percent a year from 2003 to 2006 compared with a decline of 4.7 percent a year from 2000 to 2003 - and absolute number of checks per capita- a decline of 26 checks per capita from 2003 to 2006 compared with a decline of 20 checks per capita from 2000 to 2003. Nevertheless, the United States continued to have a significantly higher number of checks per capita, albeit to a lesser extent than the years 2000 and 2003.

Among the economies considered, the number of electronic payments per capita rose fastest in the United States, at 11.4 percent a year from 2003 to 2006. By 2006, the number of electronic payments per capita surpassed the number per capita in all economies except Canada's. The U.S. check-clearing system itself is becoming more

1. The payments reported were made by both businesses and consumers. To account for differences in size among the economies, each economy's payment figures were put on a per capita basis by dividing them by the population of that economy. electronic, as may also be the case in other countries. Comparisons across economies of the number of checks and electronic payments should therefore take into consideration the extent of electronification in the various checkclearing systems.

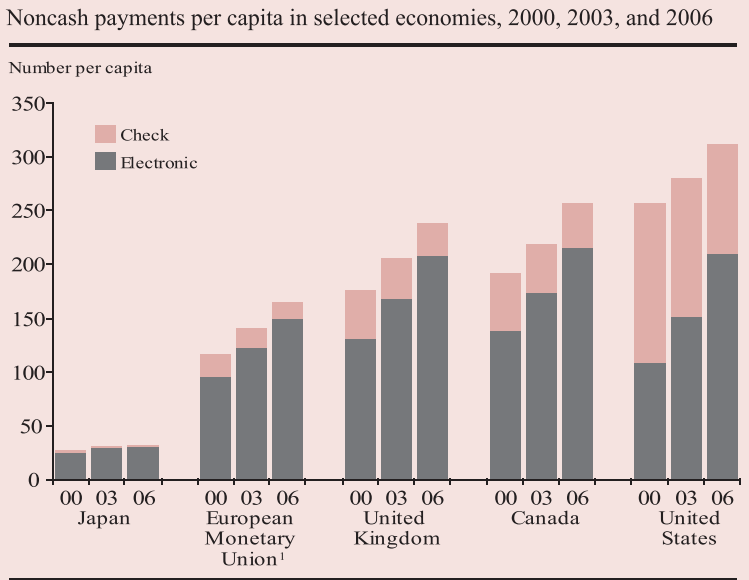

1. The European Monetary Union is made up of Austria, Belgium, Finland, France, Germany, Greece, Ireland, Italy, Luxemburg, The Netherlands, Portugal, and Spain. Cyprus, Malta, and Slovenia joined the EMU after 2006 and were not included in calculations.

SourCES: European Central Bank (2007), "Payment and Securities Settlement Systems in the European Union," August; Bank for International Settlements (2008), "Statistics on Payment Systems in the Group of Ten Countries," March; and Federal Reserve Board. conversion of checks of relatively small value not been so substantial.

\section{Checks Converted to Electronic Payments}

The number of checks converted to electronic payments in 2006 was 2.6 billion, up from 0.3 billion in 2003 (table 1), almost doubling each year. As noted earlier, about 8 percent of checks written in 2006 were converted to $\mathrm{ACH}$ payments, compared with fewer than 1 percent in 2003. These were typically checks converted by companies receiving them through the mail in payment of a bill. Some checks were tendered at the point of sale in retail establishments and were converted either at the cash register and returned to the customer once the electronic information was captured, or in the back office and then archived or destroyed.

The average value of converted checks in 2006 was $\$ 267$, up from $\$ 187$ in 2003 , for a growth rate of 12.5 percent a year. In constant 2006 dollars, however, the average value increased only 9.2 percent a year over the period. The average value of converted checks was substantially lower than the average value of paid checks, in part because $\mathrm{ACH}$ rules prohibit conversion of large-size business and other checks for large amounts. ${ }^{12}$ In fact, in 2006 the average value of converted checks, which tend to be written by consumers, was very close to the average value of checks paid by credit unions (reported below), which generally serve consumer customers.

\section{Total Checks Written}

The total number of checks written (paid checks plus converted checks) declined 4.5 billion, or 4.1 percent a year, from 2003 to 2006, compared with 3.5 percent a year from 2000 to 2003 (table 1). (Checks paid declined even more- 6.5 percent a year from 2003 to 2006 and 3.8 percent a year from 2000 to 2003.) The average value of checks written in 2006 was $\$ 1,277$.

12. Large-size business checks are typically 8 or 9 inches long and have an "auxiliary on-us" field on the MICR line. Such checks, and any check for more than $\$ 25,000$, are ineligible for conversion. 
In constant 2006 dollars, the average value increased $\$ 77$ (or 2.1 percent a year) from 2003 to 2006, compared with an increase of $\$ 92$ (or 2.7 percent a year) from 2000 to 2003.

The increase in the constant-dollar average value of checks written combined with a substantial decline in the number written suggests that most checks being replaced with electronic payments were smaller-value checks-typically, checks written by consumers and, to some extent, by businesses to consumers. Businessto-business checks, on the other hand, were likely not being replaced as rapidly. Evidence presented later indicates that consumer-to-business debit card payments are probably responsible for most of the replacement of checks written.

\section{Electronic Payments}

The number of payments made over the major electronic payment systems in the United States-the $\mathrm{ACH}$ system, debit and credit card systems, and the EBT system-grew from 44.1 billion to 62.8 billion between 2003 and 2006, for an annual rate of growth of 12.5 percent (table 1, chart 3 ). More than half the growth occurred in the debit card networks. However, among the major payment systems, the highest annual rate of growth (18.7 percent) was recorded by the $\mathrm{ACH}$ system, which started the period with a much smaller base than debit cards. Although the rate of growth of electronic payments was somewhat slower between 2003 and 2006 than between 2000 and 2003 (13.0 percent), the absolute increase in the number of electronic payments was 5.1 billion greater over the latter period.

The value of electronic payments increased more slowly than the number (8.9 percent a year compared with 12.5 percent a year), and the average value of electronic payments declined from $\$ 599$ to $\$ 544$ over the period. In constant 2006 dollars, the average value declined 6.1 percent a year. Some of this decline was due to the replacement of smaller-value checks by $\mathrm{ACH}$ payments, and some was due to the large increase in relatively small debit card payments.

Increases in the number of payments made over the major electronic payment systems are due to increasing use of both traditional and innovative ways of initiating payments. In addition, the use of privatelabel prepaid cards, an innovation not included in the figures for the major electronic payment systems, has become significant. (See the box "Innovations in Electronic Payments" for a discussion of prepaid cards and other new ways of initiating payments.)
3. Electronic payments in the United States, selected years

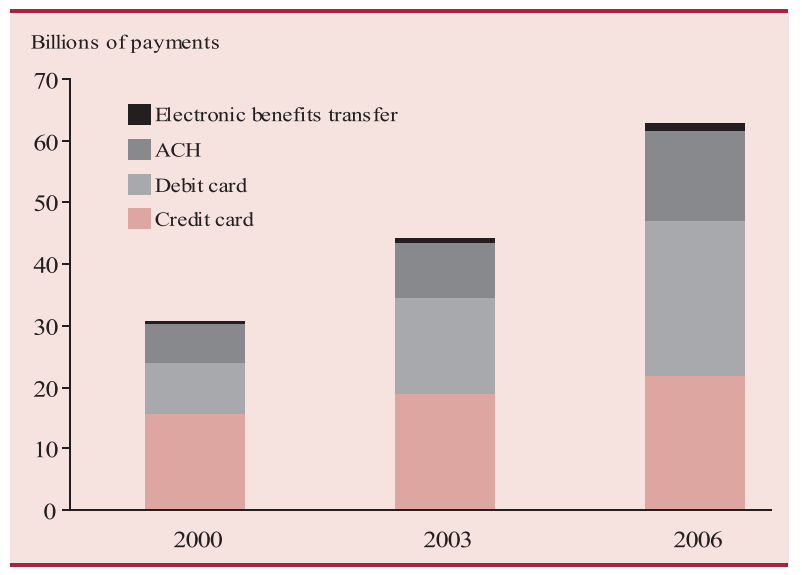

SOURCE: Federal Reserve Board.

Automated Clearinghouse Payments

An automated clearinghouse payment can be either a credit transfer or a debit transfer. A credit transfer is a transaction in which the payer's bank originates the payment, sending funds to ("crediting") the payee's bank account. A typical use of an ACH credit transfer is for payroll, with an employer initiating a "direct deposit" from its bank account into that of an employee. A debit transfer is a transaction originated by the payee's bank, which draws funds out of ("debits") the payer's bank account. The processing flow for a debit transfer is similar to the flow for a check sent by the bank of first deposit to the payer's bank for collection. Converted checks are a relatively new type of ACH debit transfer; another, more traditional type is an arrangement whereby a biller, such as an insurance or mortgage company, by prior customer authorization, periodically withdraws funds from a customer's transaction account at a depository institution.

Most of the growth in $\mathrm{ACH}$ payments between 2003 and 2006 (approximately three-fourths) came from $\mathrm{ACH}$ debit transfers, which increased 27.7 percent a year and by 2006 had surpassed credit transfers for the first time. Just over half the growth in debit transfers came from an increase in check conversion. The large majority of converted checks were checks mailed to billers and converted at so-called lockboxes, identified within the ACH system as accounts receivable check conversion (ARC) transactions (table 2). ${ }^{13}$ Growth in the conversion of checks at the

13. Rules for using the ACH system, promulgated by NACHA, require banks to identify each payment according to a set of standard entry classification (SEC) codes. References to "ARC" and similar abbreviations in this section are SEC codes. 
point of purchase (POP transactions) lagged by comparison, and back-office conversion (BOC) was new and relatively small in 2007.

An additional 1.4 billion of combined credit and debit transfer growth came from traditional prearranged payment and deposit (PPD) transactions, most likely many of which also replaced checks. Almost 1.0 billion of growth came from payments initiated over the Internet (WEB transactions). WEB transactions made at retail websites may have replaced or augmented payments made by credit or debit card, while WEB transactions made at billers' websites may have replaced checks sent through the mail.

Almost all the increase in the volume of transactions over the $\mathrm{ACH}$ system came from payments that were smaller in value than typical $\mathrm{ACH}$ payments in the past. In constant dollars, the average value of an ACH payment dropped 11 percent a year from 2003, falling to $\$ 2,121$ in 2006 . The constant-dollar average value of the debit transfer portion of ACH fell more than half, dropping 21.1 percent a year to reach $\$ 1,535$ in 2006. This huge drop in constant-dollar average value is reflected in the growth rates for debit payments, which grew less than 1 percent a year in constant-dollar value-considerably less than the 27.7 percent annual growth in number of debit payments.

Distinguishing between large-value CCD (cash concentration or disbursement) transactions (traditionally used for internal movement of corporate account balances) and the more typical business and consumer payments called "retail" (a category that includes payroll, bill payments, and some payments associated with the retail sector of the economy) gives a different picture of change (tables 1 and 2). ${ }^{14}$ As a proportion of retail ACH payments, checks converted to $\mathrm{ACH}$ payments (ARC and POP transactions) rose from only 4.5 percent in 2003 to a sizable 20.7 percent in 2006. ${ }^{15}$ The increase in such payments-ACH payments arising from check conversion-is the primary reason for the decline in

14. Traditionally, CCD transactions have been thought of as transfers initiated by large corporations to move funds between their own accounts for internal business and financial purposes; as such, they are not the focus of this article. However, a survey of members of the Association of Financial Professionals (AFP) conducted by Dove Consulting and the AFP in 2003 suggests that around half of CCDs are payments between counterparties, and not just internal transfers. The proportion of CCD value accounted for by payments between counterparties is unknown.

15. Coding for a third type of $\mathrm{ACH}$ payment arising from check conversion-back office check conversion, SEC code BOC-took effect in 2007; use of the code was not significant during the study period. the average value of $\mathrm{ACH}$ payments (and of retail $\mathrm{ACH}$ payments in particular).

While the number of CCD transactions rose 12.4 percent a year, the average value of a $\mathrm{CCD}$ payment declined almost 9 percent in constant 2006 dollars over the period. The 2006 average value was nearly one-fourth below the 2003 constant-dollar average value. Changes in the use of CCD transactions are less understood than are changes in the use of retail $\mathrm{ACH}$ payments. The decline in average value may, for example, be a sign of growing use of such transactions by smaller businesses, or a movement of some very large $\mathrm{ACH}$ payments to on-us transactions (internal to a depository institution) or to large-value funds transfer systems.

\section{Card Payments}

The number of payments made by debit, credit, or EBT card grew by 12.8 billion from 2003 to 2006, reaching 48.1 billion and exceeding the number of checks paid by 17.6 billion (table 1 , chart 3 ). Debit card payments grew more than payments of other types, rising 9.7 billion over the period and contributing three times more to card growth than other types of cards combined. By 2006, the number of debit card payments (25.3 billion) exceeded the number of credit card payments (21.7 billion).

The value of debit card payments in 2006 ( $\$ 1.0$ trillion), however, was less than half the value of credit card payments ( $\$ 2.1$ trillion). The average value of debit card payments declined to $\$ 39$ in 2006, a decrease of about $\$ 1$ from 2003. The average value of credit card payments rose to $\$ 98$, an increase of about $\$ 8$ from 2003. In constant dollars, the average value of a debit card payment decreased about 4 percent a year, while the average value of a credit card payment decreased only slightly (0.01 percent a year).

The decline in the constant-dollar average value of debit card payments and the virtually flat growth in the constant-dollar value of credit card payments suggest that much of the growth of payments by cards derived from payments of relatively small valuepayments that otherwise would quite likely have been made in cash. Data reported by some card networks suggest that a large share of card payments in 2006 were of relatively small value: an estimated 48 percent of combined debit and credit card payments (almost 23 billion) were for amounts less than $\$ 25$; 26 percent were for amounts less than $\$ 15$; and 3 percent were for amounts less than $\$ 5.16$ Of the

16. Estimates are based on data collected by Dove Consulting for the Cash Product Office at the Federal Reserve Bank of San Francisco. 


\section{Innovations in Electronic Payments}

The 2007 electronic payment survey collected information about several significant types of "emerging payments," including prepaid cards, online bill payments, person-to-person Internet payments, contactless payments, and other, less frequently used types such as proprietary $\mathrm{ACH}$ card payments, deferred payments, and mobile payments (those made from portable electronic devices such as a cellular phone). ${ }^{1}$

Electronic prepaid cards have become increasingly important replacements for paper-based payment instruments and related devices, such as gift certificates, paper tickets and tokens, and check-based rebates. ${ }^{2}$ A substantial number of prepaid cards are private-label, so-called "closed-loop" or "closed-system," cards. This type of card can be used only for purchases at, for example, a merchant's chain of stores (similar to private-label credit cards) and are often given as gifts or used to access a municipality's public transportation system. About 3 billion payments, with a total value of $\$ 36.6$ billion and an average value of $\$ 12$, are estimated to have been made in 2006 with private-label prepaid cards. ${ }^{3}$ These payments are not included in national card payment totals. If they were, they would add more than 6 percent to the number of card payments nationwide in 2006.

General-purpose, so-called "open-loop" or "opensystem," prepaid cards that can be processed on existing general-purpose credit card or debit card networks also

1. Figures for prepaid card payments reported in this box are national estimates because they include an estimated amount for the networks that did not report. Figures for other emerging payments include only reported amounts and therefore are lower bounds for the national totals. Data collection and estimation are by Dove Consulting.

2. The term "prepaid" is associated with products for which the prefunded value is recorded in a remote database that must be accessed for payment authorization. The term describes most of the prefunded cards currently in use in the United States. Most prepaid cards serve a single purpose, but some may combine multiple functions on one card. In addition, some prepaid cards, such as payroll cards, government benefit cards, and some gift cards, can be reloaded with value. For more information on prepaid cards and related business and regulatory concerns, see a summary of the November 12, 2004, Federal Reserve System Payment System Development Committee (PSDC) roundtable on storedvalue cards at www.federalreserve.gov/paymentsystems/storedvalue/ default.htm.

3. About one-third of the total was reported directly; the remainder was estimated on the basis of available information. Efforts were made to use available information to keep estimates within reasonable boundaries, but the amount of uncertainty is unknown. have been in use over the past decade. ${ }^{4}$ Uses include as gifts and for new types of electronic benefit transfers (including state-administered child support disbursement programs and unemployment insurance), international remittance payments, payment of health care expenses, and payroll. An estimated 0.3 billion open-system prepaid card payments, with a total value of $\$ 13$ billion and an average value of $\$ 41$, were made in $2006 .{ }^{5}$ As the number of closed-system prepaid card payments is estimated to have been ten times the number of open-system payments and the value three times that of open-system payments, it is clear that closed-system cards have been relatively more successful to date. The lower popularity of open-system prepaid cards may be due in part to fees charged by third-party issuers - designed to recoup costs - that are not typically charged on closed-system cards, which are essentially issued by payees. These payments are included in, but add an insignificant percentage to, national card payment totals and, depending on the network, are included in either debit card or credit card payments.

The vast majority of card payments made within the United States are still being made using magnetic stripe technology. More advanced chip-based technology, though available on so-called "smart cards" for years, remains in limited use because merchants have not extensively adopted terminals that can read them. Other technologies, such as radio frequency identification (RFID), are also being used for making payments on a limited basis. RFID technology in the form of an electronic key fob has, for example, been in use for more than a decade to make payments at the retail outlets of one large oil company (Exxon-Mobil). ${ }^{6}$ Such devices can be used to initiate individual payments from almost any debit card or credit card account. RFID technology is also being used by highway authorities to make toll transactions more convenient. At least 2 billion payments, with a value of $\$ 3.6$ billion, were initiated with RFID transponders at toll authorities in 2006. Toll transponders (such as EZPass) carry a balance and typically are

4. Like debit cards that can be authorized with a signature, some prepaid cards may bear the symbol of a major credit card network and may be used like a credit card.

5. About one-third of the total was reported directly; the remainder was estimated. Efforts were made to use available information to bound estimates, but the amount of uncertainty is unknown.

6 . The amount of use has not been reported. more than 1.4 billion card payments made for amounts of less than $\$ 5$, the majority (53 percent) were debit card payments authorized on the basis of a personal identification number (PIN).

Although data from other years are not available, it is likely that the share of relatively small payments has increased in recent years as card networks have made infrastructure and policy changes that accommodate the needs of previously cash-only merchants. For example, some quick-service restaurant chains, including McDonald's, began accepting cards at most of their locations in 2004 because of improvements 
automatically reloaded with a fixed amount once the balance drops below a set limit. ${ }^{7}$

An RFID feature has also been added to existing smart chip-based credit and debit card programs to create "contactless" cards such as MasterCard's PayPass and American Express's Express Pay. These and similar cards can be used at some gas stations, quick-service restaurants (for example, McDonalds), convenience stores (for example, 7-11 stores), and pharmacy chains (for example, CVS). Using this technology, a consumer is able to initiate a payment through the major credit or debit card networks by waving either a card or an electronic key fob near a payment terminal-rather than by swiping a card and authorizing by either PIN or signature-thereby reducing the amount of time and effort required to make a purchase. MasterCard reported that by the first quarter of 2008, the number of cards that included PayPass technology and the number of merchants accepting them both had at least doubled in a year. ${ }^{8}$ While the number and value of card payments initiated using this technology is unknown, use is most likely still low at this time.

About 3.4 billion online bill payments, with a total value of $\$ 1.2$ trillion and an average value of $\$ 345$, are estimated to have been initiated from consumer banking websites in 2006. The first consumer banking websites allowing the initiation of bill payment were reportedly introduced in the mid-1990s, shortly after commercial use of web technology began to take hold. Since then, depository institutions have increasingly offered websites capable of supporting bill payment and other types of transactions. In early 2003, fewer than half of commercial banks and state-regulated savings institutions offered transactional websites, but by early 2008, over 80 percent offered them; in early 2004, only 43 percent of federally regulated savings institutions offered them, but by early 2008, 73 percent did; and in early 2003, 29 percent of credit unions offered them, but by early 2008,58 percent did. $^{9}$

7. The reloading may be done automatically by means of credit card or through the $\mathrm{ACH}$, or by the customer initiating a payment by cash or check.

8. Although growth was significant, the totals are small compared with the total number of credit cards and the number of merchants that accept them. See Daniel Wolfe and Marc Hochstein (2008), "PayPass Issuance, Acceptance Double," American Banker, vol. 178 (May 2), p. 8.

9. Data are from depository institution reports filed with the Federal Reserve Board. These percentages represent upper bounds on the percentages of depository institution bill-payment websites because the share of these transactional websites that offer bill payment is unknown.
The number of payments initiated directly from billers' own websites, rather than depository institutions' websites, is unknown. Industry research suggests that the number was initially greater than the number of payments through banking sites. Billers may credit accounts faster, and many offer greater choice of payment instruments, allowing the use of credit or debit cards while also offering payment methods - such as online banking sites - that use the ACH system (discussed above) or that generate a so-called "remotely created check" written by the payees' bank. Some studies also suggest that payments through online banking sites could be growing faster than those made directly at billers' websites. ${ }^{10}$ Banks continue to work with large billers to provide bill presentment along with payment for customers who use their online websites. In some cases, switching to this payment method eliminates the periodic mailing of paper statements as well as the return of a check in the mail.

Over 0.5 billion emerging payments of other types, with a value of about $\$ 35$ billion and an average value of $\$ 67$, are estimated to have been made in 2006. A small number were $\mathrm{ACH}$ payments initiated with proprietary, merchantissued cards (often associated with, for example, some grocery store customer-loyalty programs), mobile payments, and deferred payments (such as those offered by Bill Me Later for certain web purchases), but the vast majority of these were person-to-person web payments. The U.S. Department of Commerce estimates that Internet (web) sales totaled about $\$ 128$ billion in 2007, compared with $\$ 28$ billion in 2000 . As a fraction of total retail sales, e-commerce grew from less than 1 percent in 2000 to over 3 percent in 2007. Thus, while Internet commerce is growing rapidly, it remains a small fraction of retail sales. As e-commerce grows, new and innovative methods of making electronic payments can also be expected to take hold.

10. Several articles in American Banker, including the following, report on some of these studies: Daniel Wolfe and Will Wade (2004), "CheckFree: Consolidators Will Win E-Billing Battle," May 21; Daniel Wolfe (2004), "Environment for EBPP Seen Shifting in Bankers' Favor," June 29; Steve Bills (2004), "The Tech Scene: Instant Credit Gives Billers Big Edge in Web Payment," October 6; Chris Costanzo (2006), "Can Banks Catch Up to Billers in Presentment?" March 28; and Steve Bills (2007), "CheckFree Deal: A Biller Willing to Use Bank Sites," December 7. allowing faster authorizations, new rules lifting signature requirements for low-value payments, and lower fees for certain types of quick-service merchants. ${ }^{17}$

17. For details see, for example, W.A. Lee (2004), "How Cards Finally Won Reluctant McDonald's Over," American Banker, vol. 169 (59), pp. 1-2.
Debit Card Payments. Debit card payments typically are authorized either with a PIN or, if it carries the Visa or MasterCard brand, by the cardholder's signature (like a credit card). In some cases, such as when a purchase is made on a merchant's website or over the telephone, the cardholder is not required to authorize the payment with a PIN or a signature. Because such payments are processed on the same 
2. ACH transactions in the United States, by type of transaction, 2003 and 2006

\begin{tabular}{|c|c|c|c|c|c|c|}
\hline \multirow[b]{2}{*}{ Type of transaction } & \multicolumn{2}{|c|}{ Number } & \multicolumn{3}{|c|}{ Value } & \multirow[b]{2}{*}{ Percent returned } \\
\hline & $\begin{array}{c}\text { Billions of } \\
\text { transactions }\end{array}$ & $\begin{array}{l}\text { Percent } \\
\text { of total }\end{array}$ & $\begin{array}{c}\text { Trillions of } \\
\text { dollars }\end{array}$ & $\begin{array}{l}\text { Percent } \\
\text { of total }\end{array}$ & $\begin{array}{l}\text { Average, } \\
\text { in dollars }\end{array}$ & \\
\hline \multicolumn{7}{|l|}{2003} \\
\hline Retail . & 7.3 & 83.8 & 8.1 & 33.6 & 1,106 & 1.5 \\
\hline $\mathrm{ARC}$ & .2 & 2.0 & .1 & .2 & 296 & .8 \\
\hline POP & .2 & 1.8 & * & $*$ & 70 & 2.0 \\
\hline PPD . & 6.0 & 68.3 & 6.4 & 26.6 & 1,072 & 1.1 \\
\hline $\mathrm{RCK}$ & * & .3 & $*$ & $*$ & 155 & 54.5 \\
\hline TEL. & .2 & 1.7 & .1 & .2 & 374 & 7.0 \\
\hline WEB & .6 & 7.0 & .2 & .7 & 291 & 1.8 \\
\hline Other & .2 & 2.6 & 1.4 & 5.8 & 6,239 & .2 \\
\hline $\mathrm{CCD} \ldots$ & 1.4 & 16.2 & 16.0 & 66.4 & 11,272 & 4 \\
\hline Total ACH transactions. & 8.8 & 100.0 & 24.1 & 100.0 & 2,754 & 1.3 \\
\hline \multicolumn{7}{|l|}{2006} \\
\hline Retail & 12.6 & 86.2 & 12.1 & 39.0 & 959 & 1.3 \\
\hline ARC & 2.3 & 15.9 & .7 & 2.2 & 290 & .4 \\
\hline POP . & .3 & 2.0 & * & .1 & 81 & 1.7 \\
\hline PPD & 7.4 & 50.4 & 8.1 & 26.2 & 1,102 & 1.1 \\
\hline $\mathrm{RCK}$ & * & .2 & $*$ & $*$ & 164 & 57.6 \\
\hline TEL. & .4 & 2.4 & .1 & .5 & 403 & 6.5 \\
\hline WEB & 1.7 & 11.3 & .6 & 2.1 & 386 & 1.5 \\
\hline Other & .6 & 4.1 & 2.5 & 8.0 & 4,194 & .2 \\
\hline $\mathrm{CCD} \ldots$ & 2.0 & 13.8 & 18.9 & 61.0 & 9,384 & 4 \\
\hline \multirow[t]{3}{*}{ Total ACH transactions. } & 14.6 & 100.0 & 31.0 & 100.0 & 2,121 & 1.1 \\
\hline & \multicolumn{2}{|c|}{ Number } & \multicolumn{3}{|c|}{ Value } & Percent returned \\
\hline & $\begin{array}{c}\text { Change } \\
\text { over period } \\
\text { (billions of } \\
\text { transactions) }\end{array}$ & $\begin{array}{l}\text { Annual } \\
\text { rate of } \\
\text { change } \\
\text { (percent) }\end{array}$ & $\begin{array}{c}\text { Change } \\
\text { over period } \\
\text { (trillions of } \\
\text { dollars) }\end{array}$ & $\begin{array}{l}\text { Annual } \\
\text { rate of } \\
\text { change } \\
\text { (percent) }\end{array}$ & $\begin{array}{l}\text { Change in } \\
\text { average } \\
\text { over period } \\
\text { (dollars) }\end{array}$ & $\begin{array}{l}\text { Change } \\
\text { over period } \\
\text { (percentage } \\
\text { points) }\end{array}$ \\
\hline \multicolumn{7}{|l|}{ Change, 2003 to 2006} \\
\hline Retail . & 5.3 & 19.8 & 4.0 & 14.3 & -147 & -.2 \\
\hline ARC & 2.1 & 137.6 & .6 & 136.0 & -6 & -.4 \\
\hline POP & .1 & 22.1 & * & 28.2 & 11 & -.3 \\
\hline PPD & 1.4 & 7.2 & 1.7 & 8.2 & 31 & $*$ \\
\hline $\mathrm{RCK}$ & * & -3.1 & $*$ & -1.2 & 9 & 3.2 \\
\hline TEL. & .2 & 32.7 & .1 & 36.1 & 29 & -.4 \\
\hline WEB & 1.0 & 39.1 & .5 & 53.0 & 96 & -.3 \\
\hline Other & .4 & 38.4 & 1.1 & 21.2 & $-2,045$ & -.1 \\
\hline $\mathrm{CCD} \ldots$ & 6 & 12.4 & 2.9 & 5.8 & $-1,888$ & $*$ \\
\hline Total ACH transactions . & 5.9 & 18.7 & 6.9 & 8.8 & -633 & -.2 \\
\hline
\end{tabular}

NoTE: Retail ACH payments include payroll, bill payments, and some payments associated with the retail sector of the economy. ARC, accounts receivable check conversion; POP, point-of-purchase check conversion; PPD, prearranged payment and deposit; RCK, re-presented check; TEL, telephone "e-check"; WEB, web "e-check." CCDs are cash concentration or disburse-

networks as signature payments, they are included in the figures for signature payments. Most debit cards can be used not only to make payments, but also to access an ATM network by entering a PIN.

The number of signature-based debit card payments in the United States grew from 10.3 billion in 2003 to 16.0 billion in 2006, for an annual growth rate of 15.8 percent. The growth, which accounted for most of the increase in debit card payments, reflects incentives offered by issuing banks to users who authorize payments with a signature rather than a PIN. The average value of a signature-based debit payment decreased from $\$ 42$ in 2003 to $\$ 40$ in 2006. In constant 2006 dollars, the average value of a signature-based debit payment was flat from 2000 to 2003 but dropped $\$ 6$ from 2003 to 2006. ment transactions, about half of which are most likely internal corporate transfers. Components may not sum to totals and may not yield percentages shown because of rounding.

1. Compound annual growth rate.

* In absolute value, less than 0.05 .

The number of debit card payments authorized with a PIN grew from 5.3 billion in 2003 to 9.4 billion in 2006. In absolute numbers, growth was greater for signature-based debit payments; but the rate of growth was greater for PIN-based payments-20.6 percent a year versus 15.8 percent a year. The average value of a PIN-based debit card payment declined from $\$ 38$ in 2003 to $\$ 37$ in 2006. In constant 2006 dollars, the average value fell $\$ 12$ from 2000 to 2003 and another \$5 from 2003 to 2006 .

When a debit card is used to make a purchase authorized with a PIN, some merchants may, on request by the user, return part of the payment in cash. Debit card purchases involving the return of cash are typically called "cash back" transactions. In such cases, the value of the payment includes both the 
value of the purchase and the value of the cash returned. The values of PIN-based debit card payments for 2003 and 2006 reported above have been adjusted to exclude an estimated portion of payment value returned in cash..$^{18}$ In 2006 an estimated 11.2 percent of PIN-based debit card payments involved the return of cash to the card user, and an estimated 8.5 percent of the total value was returned as cash. ${ }^{19}$ For PIN-based debit card payments that involved cash back, the value of the cash returned averaged about $\$ 31.20$

Credit Card Payments. Overall, the number of credit card payments grew at a relatively modest 4.6 percent a year from 2003 to 2006. The number of payments made by general-purpose credit card (Visa, MasterCard, American Express, and Discover) rose from 15.2 billion to 19.0 billion over the period, for a growth rate of 7.6 percent a year. The number of payments made by private-label credit card, typically issued by retail merchants and oil companies, dropped to 2.8 billion in 2006, declining 9.6 percent a year from 2003 to 2006 . The decline may have been influenced by an expansion of programs that co-brand store cards with general-purpose credit cards. ${ }^{21}$

Users who have been issued a PIN with their credit card can use the card to obtain a cash advance at an ATM designed to accept credit cards. Credit cards are used far less often than debit/ATM cards to obtain cash. In 2006, the number of credit card cash advances, estimated at 87 million, amounted to 0.4 percent of total credit card payments and less than 0.8 percent of total credit card value. ${ }^{22}$ These figures suggest that credit cards are probably used primarily

18. Estimates of amounts returned to card users in 2003 and 2006 were based on data provided by a few large debit card networks. The amount returned in 2000 is unknown. Therefore, how much of the decline in the average value of a PIN-based debit payment between 2000 and 2003 should be attributed to a decline in cash back, and how much to a decline in average purchase value, is unclear. All of the decline in average value between 2003 and 2006 can be attributed to a decline in average purchase value.

19. Estimates are based on information from the few debit card networks that were able to report the value of cash back and the number of PIN-based debit payments that involved the return of cash.

20. Because cash back was reported as a separate aggregate, it is not possible from the survey data to compare the average value of a PIN-based debit card payment that involved cash back with the average value of one that did not.

21. Payments by such "co-branded" cards are included in the totals for general-purpose credit cards.

22. The estimated value does not include any cash given back by a merchant as part of a credit card purchase at the point of sale. The amount given back in this way is likely to be small, as the merchant must pay the credit card network a percentage of the entire charge, including a percentage of the amount of cash given back. At least one very large merchant (Wal-Mart) reportedly allows up to \$20 in cash back on credit card purchases. to obtain cash in emergencies or when no other effective alternative exists, most likely because of the typically higher fees and lower limits on cash advances. The average value of such advances in 2006, at $\$ 190$, was considerably higher than the average value of either ATM withdrawals or cash back on debit card purchases.

\section{TRENDS IN CASH PAYMENTS}

Information on the use of cash for payments is difficult to obtain directly. Data showing a large increase in the number of card payments, in combination with reports that some formerly cash-only businesses are now accepting card payments, provide some indirect evidence that cash is increasingly being replaced by cards. Additional indirect evidence on the use of cash comes from trends in cash obtained using ATM, debit, and credit cards and from trends in per capita currency in circulation.

The number of ATM withdrawals-data collected as part of the 2004 and 2007 depository institution surveys-dropped slightly between 2003 and 2006, from 5.9 billion to 5.8 billion. The value of withdrawals rose, however, from $\$ 497$ billion to $\$ 579$ billion. The average value of a withdrawal was $\$ 100$ in 2006, compared with $\$ 85$ in 2003 , for an annual rate of growth of 5.6 percent (2.4 percent in constant dollars).

Industry reports indicate that the number of ATMs in the United States more than tripled from 1995 to 2005 (growing at 12.5 percent a year) but dropped for the first time in 2006. ${ }^{23}$ Industry data also indicate that the number of ATM transactions overallincluding cash and check deposits, cash withdrawals, electronic funds transfers, and balance inquiriesgrew from 1995 to 2004, though at a much slower pace (1.4 percent a year). Reports that the number of ATM transactions has declined since then are consistent with an increase in the number of debit card purchases involving cash back as well as other factors, such as a decrease in the use of checks, some of which would have been deposited at ATMs. The number of daily cash withdrawals per ATM averaged 43 in 2003 but had dropped to 40 by 2006.

Consumers may have been replacing ATM withdrawals with cash-back transactions partly for conve-

23. The source for 1995-2003 information on the number of ATMs is "Bank Network News and Debit Card News" (New York: Faulkner and Gray). Information on ATMs for 2004-2006 is from "EFT Data Book" (New York: Thomson Media). Also see Committee on Payment and Settlement Systems (2008), Statistics on Payment and Settlement Systems in Selected Countries: Figures for 2006 (Basel: Bank for International Settlements, March) for a variety of statistics on currency and other payment instruments (www.bis.org/publ/cpss82.pdf). 
3. Debits to transaction accounts held at depository institutions, by type and size of institution, 2007

\begin{tabular}{|c|c|c|c|c|c|c|c|c|c|c|}
\hline \multirow{2}{*}{$\begin{array}{l}\text { Type and size of } \\
\text { institution (transaction } \\
\text { deposits in millions } \\
\text { of dollars) }\end{array}$} & \multirow[b]{2}{*}{$\begin{array}{l}\text { Number of } \\
\text { institutions }\end{array}$} & \multicolumn{3}{|c|}{ Check payments $^{1}$} & \multicolumn{3}{|c|}{$\mathrm{ACH}$ payments ${ }^{2}$} & \multicolumn{3}{|c|}{ Debit card payments } \\
\hline & & $\begin{array}{l}\text { Number } \\
\text { (billions) }\end{array}$ & \begin{tabular}{|c|} 
Value \\
(trillions of \\
dollars)
\end{tabular} & $\begin{array}{l}\text { Average } \\
\text { value } \\
\text { (dollars) }\end{array}$ & $\begin{array}{l}\text { Number } \\
\text { (billions) }\end{array}$ & $\begin{array}{c}\text { Value } \\
\text { (trillions of } \\
\text { dollars) }\end{array}$ & $\begin{array}{l}\text { Average } \\
\text { value } \\
\text { (dollars) }\end{array}$ & $\begin{array}{l}\text { Number } \\
\text { (billions) }\end{array}$ & \begin{tabular}{|c|} 
Value \\
(trillions of \\
dollars)
\end{tabular} & $\begin{array}{l}\text { Average } \\
\text { value } \\
\text { (dollars) }\end{array}$ \\
\hline All institutions . & 13,316 & 29.38 & 41.164 & 1,401 & 18.07 & 142.688 & 7,896 & 30.35 & 1.244 & 41 \\
\hline 600 and above & 106 & 17.34 & 30.679 & 1,770 & 13.05 & 135.935 & 10,419 & 19.55 & .812 & 42 \\
\hline $200-599 \ldots \ldots$ & 225 & 2.50 & 2.752 & 1,100 & 1.26 & 3.068 & 2,440 & 2.66 & .104 & 39 \\
\hline $100-199$ & 475 & 1.92 & 1.848 & 963 & .93 & 1.178 & 1,273 & 2.13 & .085 & 40 \\
\hline $0-99 \ldots$ & 12,510 & 7.62 & 5.883 & 772 & 2.84 & 2.508 & 883 & 6.01 & .244 & 41 \\
\hline Commercial banks & 6,186 & 24.36 & 38.787 & 1,592 & 14.82 & 139.430 & 9,406 & 21.32 & .887 & 42 \\
\hline 600 and above & 86 & 16.09 & 29.820 & 1,854 & 11.95 & 134.011 & 11,211 & 16.78 & .698 & 42 \\
\hline $200-599 \quad \ldots \ldots$ & 141 & 1.85 & 2.432 & 1,315 & .83 & 2.675 & 3,223 & 1.23 & .049 & 40 \\
\hline $100-199 \ldots$ & 320 & 1.34 & 1.564 & 1,167 & .57 & .936 & 1,628 & .98 & .040 & 41 \\
\hline $0-99 \ldots$ & 5,639 & 5.09 & 4.970 & 977 & 1.47 & 1.809 & 1,234 & 2.34 & .100 & 43 \\
\hline Savings institutions & 1,072 & 2.28 & 1.588 & 696 & 1.57 & 2.643 & 1,684 & 3.33 & .137 & 41 \\
\hline 600 and above & 15 & 1.13 & 0.807 & 715 & .98 & 1.886 & 1,929 & 2.29 & .095 & 41 \\
\hline $200-599 \ldots \ldots$ & 28 & .24 & 0.175 & 741 & .16 & .281 & 1,767 & .30 & .012 & 41 \\
\hline $100-199 \ldots$ & 50 & .22 & 0.167 & 752 & .11 & .147 & 1,295 & .24 & .010 & 41 \\
\hline $0-99 \ldots \ldots$ & 979 & .70 & 0.439 & 631 & .32 & .329 & 1,030 & .49 & .020 & 41 \\
\hline Credit unions . & 6,058 & 2.74 & 0.789 & 288 & 1.68 & .615 & 367 & 5.70 & .220 & 39 \\
\hline 600 and above & 5 & .12 & 0.052 & 430 & .11 & .039 & 335 & .48 & .019 & 39 \\
\hline $200-599 \ldots \ldots$ & 56 & .42 & 0.145 & 348 & .27 & .111 & 414 & 1.13 & .043 & 38 \\
\hline $100-199$ & 105 & .36 & 0.118 & 329 & .24 & .096 & 403 & .91 & .035 & 38 \\
\hline $0-99 \ldots$. & 5,892 & 1.84 & 0.474 & 258 & 1.06 & .370 & 350 & 3.19 & .124 & 39 \\
\hline
\end{tabular}

Note: Annualized figures based on survey data for March and April 2007. Excludes institutions that had no transaction deposits. The number and value of debits to transaction accounts are revised from figures reported in Federal Reserve System, "The 2007 Federal Reserve Payments Study." See the appendix for details. Components may not sum to totals because of rounding.

nience and partly to avoid ATM fees. Although the number of ATM withdrawals has declined slightly, growth in cash back from debit card purchases has been quite strong. More than 1.0 billion PIN-based debit card payments in 2006 involved a return of cash to the card holder (average of \$31), compared with fewer than 0.6 billion in 2003.

The sum of the number of ATM withdrawals and PIN-based debit card payments involving cash back grew from 6.5 billion in 2003 to 6.9 billion in 2006 . As noted elsewhere, credit cards were used to obtain cash advances a relatively small number of times in 2006 ( 87 million). The total amount of cash obtained in 2006 from these sources-ATM withdrawals, cash back from debit card purchases, and credit card cash advances-was $\$ 628$ billion.

Change in the constant-dollar value per capita of low-denomination currency in circulation from 1960 to 2007 provides a long view of changes (chart 4). ${ }^{24}$ Generally, low-denomination currency has historically been used for making payments within U.S.

24. Currency in circulation-which includes all currency in the possession of consumers, businesses, and banks, except the Federal Reserve Banks, including vault cash and currency held inside ATMsreached $\$ 792$ billion at the end of 2007 .
1. Checks paid, that is, checks that were on-us (involving only one depository institution) and checks processed through the interbank check-clearing system, including original paper checks and truncated checks presented either electronically or as paper substitute checks. Does not include U.S. Treasury checks and U.S. Postal Service money orders.

2. Electronic payments processed through the automated clearinghouse system, including checks converted to electronic payments.

4. Value of low-denomination currency in circulation per capita, 1960-2007

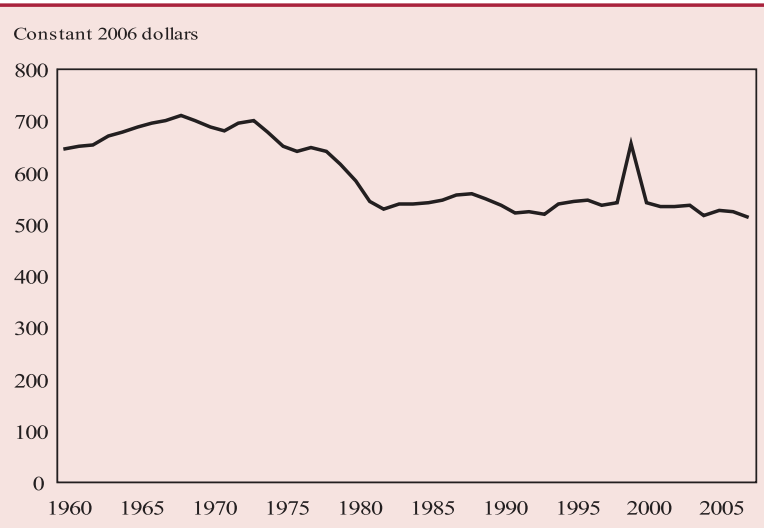

Note: Includes $\$ 1, \$ 2, \$ 5, \$ 10$, and $\$ 20$ notes.

SOURCE: Federal Reserve Board.

borders, while $\$ 50$ and $\$ 100$ notes have been used primarily as stores of value both domestically and abroad and have been used much less frequently for domestic payments. ${ }^{25}$ The constant-dollar value of low-denomination currency in circulation peaked at

25. An unknown and most likely small amount of lowdenomination currency is also used abroad. 
3.-Continued

\begin{tabular}{|c|c|c|c|c|c|c|c|c|}
\hline \multicolumn{3}{|c|}{ ATM withdrawals } & \multicolumn{3}{|c|}{ Total debits to transaction accounts } & \multicolumn{3}{|c|}{ Memo } \\
\hline $\begin{array}{l}\text { Number } \\
\text { (billions) }\end{array}$ & $\begin{array}{c}\text { Value } \\
\text { (trillions of } \\
\text { dollars) }\end{array}$ & $\begin{array}{l}\text { Average value } \\
\text { (dollars) }\end{array}$ & $\begin{array}{l}\text { Number } \\
\text { (billions) }\end{array}$ & $\begin{array}{c}\text { Value } \\
\text { (trillions of } \\
\text { dollars) }\end{array}$ & $\begin{array}{l}\text { Average value } \\
\text { (dollars) }\end{array}$ & $\begin{array}{c}\text { Transaction } \\
\text { deposits (billions } \\
\text { of dollars) }\end{array}$ & $\begin{array}{l}\text { Total deposits } \\
\text { (billions of } \\
\text { dollars) }\end{array}$ & $\begin{array}{l}\text { Total assets } \\
\text { (billions of } \\
\text { dollars) }\end{array}$ \\
\hline 5.82 & .579 & 100 & 83.62 & 185.7 & 2,220 & 843 & 7,177 & 11,196 \\
\hline 3.59 & .387 & 108 & 53.53 & 167.8 & 3,135 & 474 & 4,430 & 7,585 \\
\hline .50 & .045 & 90 & 6.92 & 6.0 & 863 & 74 & 670 & 952 \\
\hline .42 & .038 & 90 & 5.40 & 3.1 & 583 & 65 & 481 & 624 \\
\hline 1.30 & .109 & 84 & 17.78 & 8.7 & 492 & 230 & 1,596 & 2,036 \\
\hline 3.89 & .404 & 104 & 64.40 & 179.5 & 2,787 & 658 & 5,590 & 8,952 \\
\hline 3.08 & .334 & 109 & 47.90 & 164.9 & 3,442 & 409 & 3,911 & 6,740 \\
\hline .22 & .019 & 89 & 4.12 & 5.2 & 1,255 & 48 & 468 & 672 \\
\hline .18 & .016 & 90 & 3.07 & 2.6 & 833 & 44 & 303 & 402 \\
\hline .42 & .034 & 82 & 9.31 & 6.9 & 743 & 158 & 909 & 1,138 \\
\hline .67 & .067 & 99 & 7.85 & 4.4 & 565 & 95 & 958 & 1,507 \\
\hline .41 & .043 & 104 & 4.81 & 2.8 & 588 & 57 & 469 & 784 \\
\hline .07 & .007 & 95 & .77 & .5 & 619 & 9 & 89 & 145 \\
\hline .06 & .006 & 93 & .64 & .3 & 515 & 6 & 76 & 102 \\
\hline .13 & .011 & 90 & 1.63 & .8 & 490 & 22 & 324 & 475 \\
\hline 1.25 & .108 & 86 & 11.37 & 1.7 & 152 & 89 & 629 & 737 \\
\hline .10 & .010 & 96 & .81 & .1 & 146 & 8 & 50 & 61 \\
\hline .21 & .019 & 89 & 2.02 & .3 & 157 & 17 & 114 & 134 \\
\hline .19 & .017 & 89 & 1.69 & .3 & 156 & 14 & 102 & 120 \\
\hline .75 & .063 & 83 & 6.84 & 1.0 & 151 & 50 & 363 & 423 \\
\hline
\end{tabular}

around $\$ 700$ per capita in the late 1960s and early 1970s and then dropped relatively quickly until 1980, when it was around $\$ 500$ per capita. Except for small fluctuations and a brief spike in 1999 due to a temporary increase in currency stock held at banks in response to the threat of a so-called millennium bug, the constant-dollar value of currency in circulation per capita has been flat since 1980. It is possible, though only speculation, that if recent trends continue, the per capita number of cash payments may begin to decline in the near future. ${ }^{26}$

\section{PAYMENTS AND WITHDRAWALS FROM ACCOUNTS AT DEPOSITORY INSTITUTIONS}

The 2004 and 2007 depository institution surveys collected data on the number and value of several types of debits to transaction accounts-including check payments, $\mathrm{ACH}$ payments, debit card payments (both signature-based and PIN-based), and ATM withdrawals - from a representative sample of depository institutions of different types and sizes (table 3 ). ${ }^{27}$ The surveys provide enough information to study trends and variation in account debits by type and size

26. For another look at trends in the use of cash, see Paul W. Bauer and Daniel A. Littman (2007), "Are Consumers Cashing Out?" Federal Reserve Bank of Cleveland, Economic Commentary (October 1), www.clevelandfed.org/research/commentary/2007/100107.cfm.

27. Other means of debiting transaction accounts include internal transfers within a depository institution, wires over large-value funds transfer systems, and cash payments by tellers that do not involve a check. of institution and by region. Combined with another survey conducted in 2006, enough information was available to study trends and variation in the use of electronic images and paper in check processing.

The estimates reported in this section are annualized from data for March and April of 2004 and 2007 and are referred to as 2004 and 2007 estimates.

\section{Shares of Account Debits among Depository Institutions}

For purposes of estimation and data analysis, depository institutions were grouped by type-commercial banks, savings institutions, and credit unions-and, within each type, by size-largest, large, medium, and small. Collectively, the largest institutions (those with transaction deposits of $\$ 600$ million or more) continued in 2007 to pay (on their customer's behalf) the majority of account debits, with their shares of each type of payment remaining nearly the same as in 2004. In 2007, this small group, comprising fewer than 1 percent of the 13,316 depository institutions that had transaction deposits at that time, held more than 56 percent of total transaction deposits and paid 64 percent of account debits by number and more than 90 percent by value (table 4). In fact, the largest depository institutions paid most of the debits of each payment type by both number and value. Among types of account debits, the largest institutions' share by number was highest for $\mathrm{ACH}$ payments, at 72 percent, and smallest for checks, at 59 percent. 
4. Distribution of debits to transaction accounts among depository institutions, by type and size of institution, 2007 Percent

\begin{tabular}{|c|c|c|c|c|c|c|c|c|c|c|c|c|c|c|}
\hline \multirow{2}{*}{$\begin{array}{c}\text { Type and size } \\
\text { of institution } \\
\text { (transaction } \\
\text { deposits in } \\
\text { millions of } \\
\text { dollars) }\end{array}$} & \multirow{2}{*}{$\begin{array}{l}\text { Number } \\
\text { of insti- } \\
\text { tutions }\end{array}$} & \multicolumn{2}{|c|}{$\begin{array}{c}\text { Check } \\
\text { payments }^{1}\end{array}$} & \multicolumn{2}{|c|}{$\begin{array}{c}\mathrm{ACH} \\
\text { payments }\end{array}$} & \multicolumn{2}{|c|}{$\begin{array}{l}\text { Debit card } \\
\text { payments }\end{array}$} & \multicolumn{2}{|c|}{$\begin{array}{c}\text { ATM } \\
\text { withdrawals }\end{array}$} & \multicolumn{2}{|c|}{$\begin{array}{l}\text { Total debits } \\
\text { to transaction } \\
\text { accounts }\end{array}$} & \multicolumn{3}{|c|}{ Мемо } \\
\hline & & Number & Value & Number & Value & Number & Value & Number & Value & Number & Value & $\begin{array}{c}\text { Trans- } \\
\text { action } \\
\text { deposits }\end{array}$ & $\begin{array}{c}\text { Total } \\
\text { deposits }\end{array}$ & $\begin{array}{l}\text { Total } \\
\text { assets }\end{array}$ \\
\hline All institutions .. & 100.0 & 100.0 & 100.0 & 100.0 & 100.0 & 100.0 & 100.0 & 100.0 & 100.0 & 100.0 & 100.0 & 100.0 & 100.0 & 100.0 \\
\hline 600 and above & 8 & 59.0 & 74.5 & 72.2 & 95.3 & 64.4 & 65.3 & 61.8 & 66.8 & 64.0 & 90.4 & 56.2 & 61.7 & 67.7 \\
\hline $200-599 \ldots \ldots$ & 1.7 & $\begin{array}{r}39.0 \\
8.5\end{array}$ & $\begin{array}{r}14.3 \\
6.7\end{array}$ & 7.0 & 2.1 & $\begin{array}{r}04.4 \\
8.8\end{array}$ & $\begin{array}{r}0.3 \\
8.3\end{array}$ & $\begin{array}{r}01.0 \\
8.6\end{array}$ & $\begin{array}{r}00.0 \\
7.8\end{array}$ & $\begin{array}{r}04.0 \\
8.3\end{array}$ & $\begin{array}{r}90.4 \\
3.2\end{array}$ & $\begin{array}{r}50.2 \\
8.8\end{array}$ & $\begin{array}{r}01.1 \\
9.3\end{array}$ & 8.5 \\
\hline $100-199$ & $\begin{array}{l}1.1 \\
3.7\end{array}$ & $\begin{array}{l}0.5 \\
6.5\end{array}$ & 4.5 & 5.1 & $\begin{array}{r}2.1 \\
.8\end{array}$ & $\begin{array}{l}0.0 \\
7.0\end{array}$ & $\begin{array}{l}0.5 \\
6.8\end{array}$ & $\begin{array}{l}0.0 \\
7.3\end{array}$ & 6.6 & $\begin{array}{l}0.5 \\
6.5\end{array}$ & $\begin{array}{l}5.2 \\
1.7\end{array}$ & $\begin{array}{l}0.0 \\
7.7\end{array}$ & 6.7 & $\begin{array}{l}0.5 \\
5.6\end{array}$ \\
\hline $0-99 \ldots$ & 93.8 & 25.9 & 14.3 & 15.7 & 1.8 & 19.8 & 19.6 & 22.4 & 18.8 & 21.3 & 4.7 & 27.3 & 22.2 & 18.2 \\
\hline $\begin{array}{c}\text { Commercial } \\
\text { banks } \ldots . .\end{array}$ & 46.5 & 82.9 & 94.2 & 82.0 & 97.7 & 70.2 & 71.3 & 66.9 & 69.8 & 77.0 & 96.7 & 78.1 & 77.9 & 80.0 \\
\hline 600 and above & .7 & 54.7 & 72.4 & 66.2 & 93.9 & 55.3 & 56.1 & 52.9 & 57.8 & 57.3 & 88.8 & 48.5 & 54.5 & 60.2 \\
\hline $200-599 \ldots \ldots$ & 1.2 & 6.3 & 5.9 & $\begin{array}{r}00.2 \\
4.6\end{array}$ & 1.9 & 4.1 & 3.9 & 3.7 & 3.3 & 4.9 & $\begin{array}{r}00.0 \\
2.8\end{array}$ & $\begin{array}{r}40.5 \\
5.6\end{array}$ & 6.5 & 6.0 \\
\hline $100-199$ & 2.8 & 4.6 & 3.8 & 3.2 & .7 & 3.2 & 3.2 & 3.0 & 2.7 & 3.7 & 1.4 & 5.2 & 4.2 & 3.6 \\
\hline $0-99 \ldots$ & 41.9 & 17.3 & 12.1 & 8.1 & 1.3 & 7.7 & 8.0 & 7.2 & 6.0 & $\begin{array}{r}3.1 \\
11.1\end{array}$ & $\begin{array}{l}1.4 \\
3.7\end{array}$ & $\begin{array}{r}J .2 \\
18.7\end{array}$ & 12.7 & 10.2 \\
\hline $\begin{array}{l}\text { Savings } \\
\text { institutions }\end{array}$ & 8.0 & 7.8 & 3.9 & 8.7 & 1.9 & 11.0 & 11.0 & 11.6 & 11.5 & 9.4 & 2.4 & 11.3 & 13.3 & 13.5 \\
\hline 600 and above & .1 & 3.8 & 2.0 & 5.4 & 1.3 & 7.6 & 7.6 & 7.1 & 7.4 & 5.8 & 1.5 & 6.8 & 6.5 & 7.0 \\
\hline $200-599 \ldots \ldots$ & .3 & .8 & .4 & .9 & .2 & 1.0 & 1.0 & 1.2 & 1.2 & .9 & .3 & 1.1 & 1.2 & 1.3 \\
\hline $100-199$ & .4 & .8 & .4 & 6 & .1 & .8 & .8 & 1.0 & 1.0 & 8 & .2 & .8 & 1.1 & .9 \\
\hline $0-99 \ldots$. & 7.2 & 2.4 & 1.1 & 1.8 & .2 & 1.6 & 1.6 & 2.2 & 2.0 & 2.0 & .4 & 2.7 & 4.5 & 4.2 \\
\hline Credit unions . & 45.4 & 9.3 & 1.9 & 9.3 & .4 & 18.8 & 17.7 & 21.5 & 18.7 & 13.6 & .9 & 10.6 & 8.8 & 6.6 \\
\hline 600 and above & $*$ & .4 & .1 & .6 & $*$ & 1.6 & 1.5 & 1.7 & 1.7 & 1.0 & .1 & .9 & .7 & .5 \\
\hline $200-599 \ldots \ldots$ & .2 & 1.4 & .4 & 1.5 & .1 & 3.7 & 3.4 & 3.6 & 3.3 & 2.4 & .2 & 2.0 & 1.6 & 1.2 \\
\hline $100-199 \quad \ldots \ldots \ldots$ & .6 & 1.2 & 3 & 1.3 & .1 & 3.0 & 2.8 & 3.2 & 2.9 & 2.0 & .1 & 1.7 & 1.4 & 1.1 \\
\hline $0-99 \ldots \ldots \ldots \ldots$ & 44.6 & 6.3 & 1.2 & 5.8 & .3 & 10.5 & 10.0 & 13.0 & 10.9 & 8.2 & 6 & 5.9 & 5.1 & 3.8 \\
\hline
\end{tabular}

NoTE: Percentages based on annualized figures derived from survey data for March and April 2007. Excludes institutions that had no transaction deposits. The number and value of debits to transaction accounts are revised from figures reported in Federal Reserve System, "The 2007 Federal Reserve Payments Study." See the appendix for details. Components may not sum to totals because of rounding.

By type, commercial banks, which serve a broad range of customers, including consumers and large corporations, held the majority of transaction deposits (78.1 percent) and assets (80.0 percent) in 2007. About 77.0 percent of account debits by number, and 96.7 percent by value, were paid from accounts at these banks. The second largest type of depository institution, as measured by both transaction deposits (11.3 percent) and assets (13.5 percent), were savings institutions, which generally serve consumer and business customers, but not the largest corporations; 9.4 percent of account debits, representing 2.4 percent of total account debit value, were paid from accounts at these institutions. Credit unions, which generally serve consumer customers rather than businesses, had the smallest share of transaction deposits (10.6 percent) and assets (6.6 percent). Although they accounted for a larger proportion of account debits by number (13.6 percent) than did savings institutions, they accounted for a smaller proportion by value (less than 1 percent).
1. Checks paid, that is, checks that were on-us (involving only one depository institution) and checks processed through the interbank check-clearing system, including original paper checks and truncated checks presented either electronically or as paper substitute checks. Does not include U.S. Treasury checks and U.S. Postal Service money orders.

2. Electronic payments processed through the automated clearinghouse system, including checks converted to electronic payments.

$*$ In absolute value, less than 0.05 .

As in 2004, the average value of account debits in 2007 varied with depository institution size. For ACH payments in particular, a substantial amount of value (93.9 percent) was concentrated at the largest commercial banks, compared with 66.2 percent by number. A substantial portion of this value can be explained by unusually high average $\mathrm{ACH}$ values at a handful of institutions. As discussed later in the section "On Us Payments," much of this concentration in $\mathrm{ACH}$ value is from internal payments.

Generally, the average values of ACH and check payments increase in tandem with increasing commercial bank size because of the greater presence of large business customers at larger commercial banks. ${ }^{28}$ The group with the lowest average values for $\mathrm{ACH}$ and check payments was credit unions, which,

28. In 2000 the average value of checks written by consumers was about $\$ 350$, and by businesses, $\$ 1,700$. These are the author's own estimates based on a study in which individual checks that could be classified were sorted by payer. See Federal Reserve System (2002), "Retail Payment Research Project: A Snapshot of the U.S. Payments 
as previously noted, typically do not handle transaction accounts for businesses. The average value of debit card payments did not vary significantly with depository institution type or size, while average ATM withdrawals generally were larger at the largest institutions.

\section{Changes in Shares from 2004 to 2007}

The share of checks paid by commercial banks increased 2.6 percentage points from 2004 to 2007, reaching 82.9 percent (despite a decline of almost 4.7 billion in the number of checks paid). The share of checks paid by credit unions dropped 2.2 percentage points over the period, to 9.3 percent. The share of checks paid by savings institutions remained relatively flat, dropping only 0.4 percentage point. This pattern-decreasing share of checks for credit unions, which generally serve only consumers, and increasing share for commercial banks, which serve businesses in addition to consumers-provides evidence that consumers' use of checks is declining faster than businesses' use of checks. The decrease for credit unions is due both to fewer checks being written by credit union customers and to more of these customers' checks being converted to $\mathrm{ACH}$ payments.

The share of $\mathrm{ACH}$ payments at savings institutions increased markedly from 2004 to 2007 (from 4.9 percent to 8.7 percent) because of a relatively large increase in the number of such payments at those institutions (from 0.5 billion to 1.6 billion, about 45 percent a year). In contrast to the 3.8 percentage point annual increase in share by number was a 0.6 percentage point annual decline in share by value, leading to a steep drop in the average value of $\mathrm{ACH}$ payments at savings institutions (26.4 percent a year). A significant increase in the conversion of smallvalue consumer checks into $\mathrm{ACH}$ payments and a decrease in the number of large-value $\mathrm{ACH}$ payments reported (due to greater accuracy on the part of some institutions) most likely were factors in these changes. ${ }^{29}$

\section{Distribution of \\ Depository Institutions' Account Debits}

Overall, in 2007 about 36 percent of account debits were made by debit card, 35 percent were made by check, 22 percent were $\mathrm{ACH}$ payments, and 7 percent

Landscape,” pp. 12-14, www.frbservices.org/files/communications/ pdf/research/RetailPaymentsResearchProject.pdf.

29. See the appendix for details on changes in reporting accuracy. were cash withdrawals from ATMs (table 5). ${ }^{30}$ The distribution had changed substantially from 2004, when 26 percent of account debits were made by debit card, 51 percent were made by check, 15 percent were $\mathrm{ACH}$ payments, and 8 percent were cash withdrawals from ATMs. In 2004, checks were the predominant payment type at institutions of all types; by 2007 , debit cards had become the predominant payment type overall, and predominant at credit unions, savings institutions, and the largest commercial banks, while checks continued to be predominant at smaller commercial banks.

At institutions of all types, check payments as a proportion of all debits to transaction accounts declined between 2004 and 2007-from 43 percent to 24 percent at credit unions; from 47 percent to 29 percent at savings institutions; and from 53 percent to 38 percent at commercial banks. ${ }^{31}$ In 2007, as in 2004, there was an inverse relationship between the size of a given type of institution and its proportion of the total that were check payments: generally, the larger the institution, the smaller the share of checks with respect to total account debits. For commercial banks, the proportion of check payments at small banks (those with less than $\$ 100$ million in deposits) was about 55 percent, and at the largest banks, 34 percent. The proportion of checks may be smaller at larger depository institutions because larger institutions may provide for (and perhaps encourage) greater use of ACH and debit cards. Larger depository institutions may also serve more-sophisticated or larger customers that may be more willing or able than less-sophisticated or smaller customers to take advantage of cost savings or other benefits afforded by other types of payment.

In contrast to checks, $\mathrm{ACH}$ payments as a proportion of all debits to transaction accounts increased at institutions of all types between 2004 and 2007from 9 percent to 15 percent at credit unions; from 8 percent to 20 percent at savings institutions; and from 17 percent to 23 percent at commercial banks. At commercial banks, the proportion of ACH payments by number increased with increasing size, possibly because of greater use of ACH by large corporate account holders. The proportion of $\mathrm{ACH}$

30. The shares of account debits at depository institutions overall differ from the shares of corresponding payments in total noncash payments (as reported in table 1), mainly because debits to deposit accounts include ATM withdrawals and do not include credit card payments.

31. Generally, $\mathrm{ACH}$ and debit card payments grew as a proportion of account debits between 2004 and 2007, and check payments and ATM withdrawals declined as a proportion, across institutions of all types and sizes. 
5. Distribution of debits to transaction accounts at depository institutions, by type of debit, 2007

Percent

\begin{tabular}{|c|c|c|c|c|c|c|c|c|c|c|}
\hline \multirow{2}{*}{$\begin{array}{l}\text { Type and size of } \\
\text { institution (transaction } \\
\text { deposits in millions } \\
\text { of dollars) }\end{array}$} & \multicolumn{2}{|c|}{ Check payments ${ }^{1}$} & \multicolumn{2}{|c|}{ ACH payments ${ }^{2}$} & \multicolumn{2}{|c|}{ Debit card payments } & \multicolumn{2}{|c|}{ ATM withdrawals } & \multicolumn{2}{|c|}{$\begin{array}{l}\text { Total debits to } \\
\text { transaction accounts }\end{array}$} \\
\hline & Number & Value & Number & Value & Number & Value & Number & Value & Number & Value \\
\hline All institutions . & 35.1 & 22.2 & 21.6 & 76.8 & 36.3 & .7 & 7.0 & .3 & 100.0 & 100.0 \\
\hline $\begin{array}{l}600 \text { and above } \\
200-599 \ldots \ldots \\
100-199 \ldots \ldots \\
0-99 \ldots \ldots \ldots\end{array}$ & $\begin{array}{l}32.4 \\
36.2 \\
35.5 \\
42.9\end{array}$ & $\begin{array}{l}18.3 \\
46.1 \\
58.7 \\
67.3\end{array}$ & $\begin{array}{l}24.4 \\
18.2 \\
17.1 \\
16.0\end{array}$ & $\begin{array}{l}81.0 \\
51.4 \\
37.4 \\
28.7\end{array}$ & $\begin{array}{l}36.5 \\
38.4 \\
39.5 \\
33.8\end{array}$ & $\begin{array}{r}.5 \\
1.7 \\
2.7 \\
2.8\end{array}$ & $\begin{array}{l}6.7 \\
7.2 \\
7.8 \\
7.3\end{array}$ & $\begin{array}{r}.2 \\
.8 \\
1.2 \\
1.2\end{array}$ & $\begin{array}{l}100.0 \\
100.0 \\
100.0 \\
100.0\end{array}$ & $\begin{array}{l}100.0 \\
100.0 \\
100.0 \\
100.0\end{array}$ \\
\hline Commercial banks & 37.8 & 21.6 & 23.0 & 77.7 & 33.1 & .5 & 6.0 & .2 & 100.0 & 100.0 \\
\hline $\begin{array}{l}600 \text { and above } \\
200-599 \ldots \ldots \\
100-199 \ldots \ldots \\
0-99 \ldots \ldots \ldots\end{array}$ & $\begin{array}{l}33.6 \\
44.8 \\
43.7 \\
54.7\end{array}$ & $\begin{array}{l}18.1 \\
47.0 \\
61.2 \\
71.9\end{array}$ & $\begin{array}{l}25.0 \\
20.1 \\
18.7 \\
15.7\end{array}$ & $\begin{array}{l}81.3 \\
51.7 \\
36.6 \\
26.2\end{array}$ & $\begin{array}{l}35.0 \\
29.8 \\
31.8 \\
25.1\end{array}$ & $\begin{array}{r}.4 \\
.9 \\
1.6 \\
1.4\end{array}$ & $\begin{array}{l}6.4 \\
5.2 \\
5.7 \\
4.5\end{array}$ & $\begin{array}{l}.2 \\
.4 \\
.6 \\
.5\end{array}$ & $\begin{array}{l}100.0 \\
100.0 \\
100.0 \\
100.0\end{array}$ & $\begin{array}{l}100.0 \\
100.0 \\
100.0 \\
100.0\end{array}$ \\
\hline Savings institutions & 29.1 & 35.8 & 20.0 & 59.6 & 42.4 & 3.1 & 8.6 & 1.5 & 100.0 & 100.0 \\
\hline $\begin{array}{l}600 \text { and above } \\
200-599 \ldots \ldots \\
100-199 \ldots \ldots \\
0-99 \ldots \ldots \ldots\end{array}$ & $\begin{array}{l}23.5 \\
30.8 \\
34.7 \\
42.6\end{array}$ & $\begin{array}{l}28.5 \\
36.9 \\
50.7 \\
54.9\end{array}$ & $\begin{array}{l}20.3 \\
20.7 \\
17.7 \\
19.6\end{array}$ & $\begin{array}{l}66.6 \\
59.1 \\
44.6 \\
41.2\end{array}$ & $\begin{array}{l}47.7 \\
39.1 \\
38.1 \\
30.0\end{array}$ & $\begin{array}{l}3.4 \\
2.6 \\
3.0 \\
2.5\end{array}$ & $\begin{array}{l}8.6 \\
9.4 \\
9.5 \\
7.8\end{array}$ & $\begin{array}{l}1.5 \\
1.4 \\
1.7 \\
1.4\end{array}$ & $\begin{array}{l}100.0 \\
100.0 \\
100.0 \\
100.0\end{array}$ & $\begin{array}{l}100.0 \\
100.0 \\
100.0 \\
100.0\end{array}$ \\
\hline Credit unions & 24.1 & 45.6 & 14.8 & 35.5 & 50.2 & 12.7 & 11.0 & 6.2 & 100.0 & 100.0 \\
\hline $\begin{array}{l}600 \text { and above } \\
200-599 \ldots \ldots \\
100-199 \ldots \ldots \\
0-99 \ldots \ldots \ldots\end{array}$ & $\begin{array}{l}15.0 \\
20.6 \\
21.1 \\
26.9\end{array}$ & $\begin{array}{l}44.0 \\
45.7 \\
44.4 \\
46.0\end{array}$ & $\begin{array}{l}14.1 \\
13.3 \\
14.0 \\
15.5\end{array}$ & $\begin{array}{l}32.4 \\
35.0 \\
36.1 \\
35.9\end{array}$ & $\begin{array}{l}58.6 \\
55.7 \\
53.9 \\
46.6\end{array}$ & $\begin{array}{l}15.6 \\
13.4 \\
13.2 \\
12.0\end{array}$ & $\begin{array}{l}12.3 \\
10.5 \\
11.0 \\
11.0\end{array}$ & $\begin{array}{l}8.1 \\
5.9 \\
6.3 \\
6.1\end{array}$ & $\begin{array}{l}100.0 \\
100.0 \\
100.0 \\
100.0\end{array}$ & $\begin{array}{l}100.0 \\
100.0 \\
100.0 \\
100.0\end{array}$ \\
\hline
\end{tabular}

NotE: Percentages based on annualized figures derived from survey data for March and April 2007. Excludes institutions that had no transaction deposits. The number and value of debits to transaction accounts are revised from figures reported in Federal Reserve System, "The 2007 Federal Reserve Payments Study." See the appendix for details. Components may not sum to totals because of rounding.

payments for savings institutions and credit unions did not show a clear relationship with size.

The proportion of debit card payments in account debits for credit unions was just over 50 percent, higher than the proportion for savings institutions (42 percent) and commercial banks (33 percent). Similarly, the proportion of ATM withdrawals was greater for savings institutions and credit unions9 percent and 11 percent, respectively-than for commercial banks (6 percent). That debit card payments and ATM withdrawals are proportionally more prevalent at credit unions than at other types of institutions is not unexpected, given their base of primarily consumer customers.

Estimates from the 2007 depository institution survey indicate that signature-based debit card payments, at 19.1 billion (63 percent of total debit card payments), were not quite twice as common as PINbased debit card payments, at 11.2 billion ( 37 percent of total debit card payments). Estimates from the 2004 depository institution survey were in similar proportion-11.7 billion ( 65 percent) signature-based and 6.3 billion (35 percent) PIN-based. The ratio of signature-based to PIN-based debit card payments was roughly similar across institutions of different
1. Checks paid, that is, checks that were on-us (involving only one depository institution) and checks processed through the interbank check-clearing system, including original paper checks and truncated checks presented either electronically or as paper substitute checks. Does not include U.S. Treasury checks and U.S. Postal Service money orders.

2. Electronic payments processed through the automated clearinghouse system, including checks converted to electronic payments.

types and sizes. There was, however, substantial variation among responding institutions within size and type categories.

\section{Electronic and Paper Check Processing}

The traditional method of collecting a check is to deposit it at a depository institution, which, if the check is drawn on a different institution (an "interbank check"), then collects the funds by presenting the original paper check to the institution responsible for paying it, the "paying bank." Presentment to the paying bank is done either directly or through one or more intermediaries or agents, such as a Federal Reserve Bank or a private clearinghouse. Use of original paper checks requires timely physical sorting and transportation, often to remote, small-volume locations, making this method of check clearing relatively costly compared with modern electronic methods.

As an alternative to the presentment of original checks, some depository institutions have for decades, by agreement, transmitted electronic information about the checks they present. In this form of check presentment-a method historically called electronic 
6. Checks paid by depository institutions, by form of presentment, and electronic checks deposited, 2007

\begin{tabular}{|c|c|c|c|c|c|}
\hline \multirow[b]{2}{*}{ Item } & \multicolumn{2}{|c|}{ Number } & \multicolumn{3}{|c|}{ Value } \\
\hline & $\begin{array}{l}\text { Billions of } \\
\text { checks }\end{array}$ & $\begin{array}{c}\text { Percent of } \\
\text { interbank checks }\end{array}$ & $\begin{array}{l}\text { Trillions of } \\
\text { dollars }\end{array}$ & $\begin{array}{c}\text { Percent of } \\
\text { interbank checks }\end{array}$ & $\begin{array}{l}\text { Average, } \\
\text { in dollars }\end{array}$ \\
\hline Checks paid $^{1}$ & 29.4 & & 41.2 & & 1,401 \\
\hline Interbank checks & 23.3 & 100.0 & 29.3 & 100.0 & 1,256 \\
\hline Paper ......... & 16.7 & 71.7 & 21.8 & 74.4 & 1,303 \\
\hline Original & 13.3 & 56.9 & 15.6 & 53.1 & 1,172 \\
\hline Substitute & 3.0 & 12.6 & 5.7 & 19.5 & 1,936 \\
\hline ECP $\ldots \ldots$ & .5 & 2.2 & .6 & 1.9 & 1,064 \\
\hline Electronic ......... & 6.6 & 28.3 & 7.5 & 25.6 & 1,137 \\
\hline Image $\ldots \ldots \ldots \ldots$ & 6.4 & 27.5 & 7.4 & 25.4 & 1,161 \\
\hline MICR & .2 & .8 & .1 & .2 & 280 \\
\hline On-us checks & 6.1 & $\ldots$ & 11.9 & $\ldots$ & 1,958 \\
\hline \multicolumn{6}{|l|}{ Electronic checks deposited ${ }^{2}$} \\
\hline Client image.... & 1.4 & $\ldots$ & 2.5 & ( & 1,697 \\
\hline Branch/ATM image & 2.1 & $\ldots$ & 2.0 & . & 927 \\
\hline \multicolumn{6}{|l|}{ Мемо } \\
\hline Checks converted to $\mathrm{ACH}$ & 3.3 & & .8 & & 260 \\
\hline
\end{tabular}

NotE: Annualized figures based on survey data for March and April 2007. Excludes institutions that had no transaction deposits. The number and value of checks are revised from figures reported in Federal Reserve System, "The 2007 Federal Reserve Payments Study." See the appendix for details. Components may not sum to totals because of rounding.

1. Does not include U.S. Treasury checks and U.S. Postal Service money orders. A substitute check is a special paper copy of the original check. ECP is electronic check presentment with a paper check to follow, also called

check presentment (ECP) - the paper checks are typically also delivered to the paying bank. But doing this for all checks would require banks to obtain agreements with all counterparties - including a very large number of institutions to which checks are presented infrequently and in small volume. Further, as noted, ECP typically includes the delivery of the paper checks to the paying bank, limiting the amount of cost savings that can be obtained. In the past, many depository institutions preferred the status quoexchanging original paper checks, which increased float for the paying bank-to adopting electronic check-clearing methods. ${ }^{32}$ Thus, even with some potential benefits, depository institutions and their agents were unable to substantially expand the proportion of checks they presented electronically. In 2007, an estimated 0.5 billion checks were presented by ECP (table 6).

With the changes governing check processing resulting from the Check 21 law, banks may now truncate all checks and replace them with electronic images, presenting them electronically to paying banks that agree or as paper substitute checks to those

32. See James McAndrews and William Roberds (2000), "The Economics of Check Float," Federal Reserve Bank of Atlanta, Economic Review, vol. 85 (4th quarter), pp. 17-27, for a discussion of the issues. same-day settlement. Electronic checks do not involve presentment of a paper check and include checks presented as images as well as checks presented using only data from the magnetic ink character recognition (MICR) line at the bottom of the check.

2. Client images are checks remotely deposited electronically as images by bank customers. Branch/ATM images are checks imaged either at an ATM or within a branch and forwarded on for collection. Not applicable.

that require paper. ${ }^{33}$ The Reserve Banks and some private clearinghouses are facilitating the transition to the use of electronics by offering incentives for depositing electronic images of checks and accepting electronic images for presentment.

The costs and benefits of adopting electronic check image processing vary, are changing rapidly, and can be influenced by a variety of factors. For institutions that outsource some part of check processing, the timing of adoption may depend on when correspondent banks or third-party processors adopt. Each depository institution chooses a time to adopt on the basis of the expected future costs and benefits of adopting at that time. In the long run, all depository institutions that process checks most likely will adopt electronic image processing methods.

Survey data collected in 2006 and 2007 indicate that there have already been rapid changes in the number of checks deposited and presented electronically and in the percentage of depository institutions accepting electronic image presentment. Data from early 2007 show that at that time there were meaningful differences in the level of adoption of electronic

33. As noted in the introduction to this article, Check 21 (Check Clearing for the 21st Century Act) removed a legal impediment to the replacement, during the collection process, of paper checks with electronic information ("check truncation"). Under Check 21, a paying bank that does not accept electronic images of checks for payment must accept a "substitute check." For additional information, see www.federalreserve.gov/paymentsystems/truncation/default.htm. 
7. Distribution of interbank checks paid by depository institutions, by form of presentment, 2007 Percent

\begin{tabular}{|c|c|c|c|c|c|c|}
\hline \multirow{2}{*}{$\begin{array}{l}\text { Type and size of institution } \\
\text { (transaction deposits } \\
\text { in millions of dollars) }\end{array}$} & \multicolumn{2}{|c|}{ Paper } & \multicolumn{2}{|c|}{ Electronic } & \multicolumn{2}{|c|}{ Total } \\
\hline & Number & Value & Number & Value & Number & Value \\
\hline All institutions & 71.7 & 74.4 & 28.3 & 25.6 & 100.0 & 100.0 \\
\hline Commercial banks & 69.8 & 73.7 & 30.2 & 26.3 & 100.0 & 100.0 \\
\hline $\begin{array}{l}600 \text { and above . } \\
200-599 \ldots \ldots \ldots \\
100-199 \ldots \ldots \ldots \\
0-99 \ldots \ldots \ldots \ldots\end{array}$ & $\begin{array}{l}69.2 \\
84.3 \\
72.2 \\
65.6\end{array}$ & $\begin{array}{l}73.9 \\
83.6 \\
68.4 \\
69.6\end{array}$ & $\begin{array}{l}30.8 \\
15.7 \\
27.8 \\
34.4\end{array}$ & $\begin{array}{l}26.1 \\
16.4 \\
31.6 \\
30.4\end{array}$ & $\begin{array}{l}100.0 \\
100.0 \\
100.0 \\
100.0\end{array}$ & $\begin{array}{l}100.0 \\
100.0 \\
100.0 \\
100.0\end{array}$ \\
\hline Savings institutions & 91.9 & 91.9 & 8.1 & 8.1 & 100.0 & 100.0 \\
\hline $\begin{array}{l}600 \text { and above .. } \\
200-599 \ldots \ldots \ldots \\
100-199 \ldots \ldots \ldots \\
0-99 \ldots \ldots \ldots \ldots\end{array}$ & $\begin{array}{l}96.7 \\
94.2 \\
89.2 \\
83.9\end{array}$ & $\begin{array}{l}96.6 \\
94.0 \\
91.1 \\
82.6\end{array}$ & $\begin{array}{r}3.3 \\
5.8 \\
10.8 \\
16.1\end{array}$ & $\begin{array}{r}3.4 \\
6.0 \\
8.9 \\
17.4\end{array}$ & $\begin{array}{l}100.0 \\
100.0 \\
100.0 \\
100.0\end{array}$ & $\begin{array}{l}100.0 \\
100.0 \\
100.0 \\
100.0\end{array}$ \\
\hline Credit unions . & 70.4 & 71.8 & 29.6 & 28.2 & 100.0 & 100.0 \\
\hline $\begin{array}{l}600 \text { and above } \ldots \ldots \ldots \ldots \ldots \\
200-599 \ldots \ldots \ldots \ldots \ldots \ldots \ldots \ldots \\
100-199 \ldots \ldots \ldots \ldots \ldots \ldots \ldots \ldots \ldots \ldots \ldots \ldots \ldots \\
0-99 \ldots \ldots \ldots \ldots \ldots \ldots \ldots \ldots \ldots \ldots\end{array}$ & $\begin{array}{l}98.0 \\
78.0 \\
78.6 \\
65.2\end{array}$ & $\begin{array}{l}97.9 \\
80.3 \\
80.6 \\
64.0\end{array}$ & $\begin{array}{r}2.0 \\
22.0 \\
21.4 \\
34.8\end{array}$ & $\begin{array}{r}2.1 \\
19.7 \\
19.4 \\
36.0\end{array}$ & $\begin{array}{l}100.0 \\
100.0 \\
100.0 \\
100.0\end{array}$ & $\begin{array}{l}100.0 \\
100.0 \\
100.0 \\
100.0\end{array}$ \\
\hline
\end{tabular}

NOTE: Percentages based on annualized figures derived from survey data for March and April 2007.

image processing among groups of institutions, revealing that the timing of adoption was related to institution size and type. However, there were also substantial differences between institutions within groups, evidence that size and type are not the only important indicators of the timing of adoption.

Monthly data also reveal that between the reference period of the 2007 survey (March and April) and June 2008, the proportion of checks deposited with and presented by the Federal Reserve Banks as electronic check images increased substantially, as did the proportion of institutions depositing and receiving such images through the Reserve Banks. The rapid increases reflect more-recent changes within the interbank check-clearing system overall and suggest that the differences among groups of institutions are less pronounced now. If, as expected, the rapid adoption of electronic check image processing continues, the check-clearing system will become predominantly electronic within only a few years. ${ }^{34}$

\section{Checks Paid, by Form of Presentment}

A depository institution that requires presentment of a paper check receives either the original check or, if the check was truncated and replaced with an electronic image, a substitute check. Figures based on data for March and April 2007 suggest that at that time, an annualized 13.3 billion original interbank

34. Checks converted to electronic $\mathrm{ACH}$ payments and therefore not processed within the check-clearing system are outside the scope of this discussion. checks and about 3.0 billion substitute interbank checks were being presented (table 6). ${ }^{35}$ Another 6.6 billion interbank checks were being presented electronically (28.3 percent of interbank checks). Most of these ( 6.4 billion) were presented as images; the remainder were "MICR presentments," whereby only limited information about the check (account number and dollar amount) is provided to the paying bank at the time of presentment. ${ }^{36}$ In all, an annualized 9.5 billion checks, or 40.9 percent of interbank checks, were truncated and presented electronically or as substitute checks in 2007.

Commercial banks and credit unions paid paper and electronic interbank checks in about the same proportions in 2007: roughly 70 percent paper and 30 percent electronic (table 7). Savings institutions, at over 90 percent paper and fewer than 10 percent electronic, paid a much smaller proportion of checks electronically or as substitute checks.

For each type of depository institution, the proportion of checks presented to them electronically generally increased with decreasing size. One explanation could be that small institutions are more likely than medium-size and large institutions to use intermediaries, such as third-party processors or correspondent banks, that take advantage of the economies of scale and scope available with electronic check processing.

35. Another 0.5 billion checks were presented using ECP, that is, same-day settlement with paper to follow.

36. Additional information, such as an image of the check, is not routinely provided with MICR presentments but generally can be provided on request. 
Such intermediaries play an important role in the adoption of electronic check image processing because they can help depository institution customers adopt sooner by, for example, providing incentives and standardized processes for receiving electronic check image presentment. Smaller institutions may also be better able to use "off-the-shelf" electronic check processing solutions that can help speed adoption. Among commercial banks, the largest received a high proportion of electronic check images compared with large and medium-size banks. The largest commercial banks may have adapted their proprietary check-processing systems to handle electronic check presentments sooner because they have greater opportunities for cost savings from economies of scale and scope and the capacity to manage multiple platforms.

When a depository institution adopts technology enabling it to accept electronically presented interbank checks, the extra cost of simultaneously supporting two technologies (traditional paper and new electronic technology) creates incentives to stop supporting paper technology. ${ }^{37}$ The survey data provide evidence that most depository institutions use mainly one or the other technology. About 85 percent of institutions received nearly all check presentments in either paper or electronic form in April 2007. A plot of survey respondents by the proportion of interbank checks they received in electronic form reveals that most respondents were concentrated at the tails of the distribution, meaning that most responding institutions in the sample received almost all check presentments in one form or the other (chart 5). At least some depository institutions, however, apparently supported both forms of check presentment, as an estimated 15 percent received between 10 and 90 percent of interbank checks as truncated checks. ${ }^{38}$ Some of these institutions may have continued the exchange of local paper checks through clearinghouses when it was cost effective to do so while receiving other checks in electronic form, and some may have been in the midst of a transition to receiving all interbank checks electronically.

Overall, an estimated 42 percent of depository institutions received at least some interbank check presentments in electronic form (table 8). ${ }^{39}$ The pro-

37. Because a paper check presented over the counter at a bank may not be refused, some paper processing is inevitable. But depository institutions may create electronic images of any paper checks they receive.

38. Depository institutions that receive some paper may or may not create electronic images of the checks for internal processing purposes.

39. Estimates are based on the portion of complete survey responses for check payments that did not require the use of imputed data (see the appendix).
5. Distribution of responding institutions by the proportion of interbank checks they received in electronic form, 2007

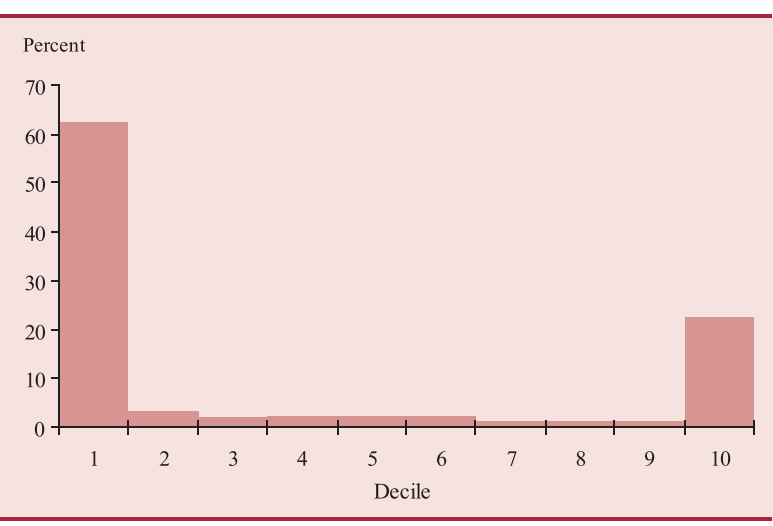

NoTE: The proportion of interbank checks presented electronically to the depository institutions ranged from 0 to 100 percent. In this chart, the range is divided into deciles, and each bar shows the percentage of respondents whose proportions fell within that increment. For example, the bar labeled decile 1 shows the percentage of depository institutions that reported receiving up to 10 percent of the interbank checks presented to them in electronic form.

portion receiving some or all checks in paper or electronic form varied by size and type of institution. About half of the largest and medium-size commercial banks received at least some electronic checks, while about 40 percent of the large and small ones did. For credit unions, the proportion of institutions accepting electronic presentment increased with decreasing size, rising from about 25 percent of the largest to 46 percent of the smallest. Only 17 percent of the largest savings institutions received some

8. Depository institutions receiving interbank check presentments in electronic form, 2007

Percent

\begin{tabular}{|c|c|c|}
\hline $\begin{array}{l}\text { Type and size of institution } \\
\text { (transaction deposits in } \\
\text { millions of dollars) }\end{array}$ & Some electronic & All electronic \\
\hline All institutions $\ldots \ldots \ldots \ldots$ & 41.6 & 24.4 \\
\hline Commercial banks & 40.8 & 22.0 \\
\hline 600 and above & 50.9 & .0 \\
\hline $200-599 \ldots \ldots$ & 38.6 & 5.3 \\
\hline $100-199$ & 50.6 & 18.4 \\
\hline $0-99$ & 40.2 & 23.0 \\
\hline Savings institutions & 25.6 & 16.1 \\
\hline 600 and above & 16.7 & .0 \\
\hline $200-599 \ldots \ldots$ & 50.0 & 12.5 \\
\hline $100-199$ & 35.3 & 5.9 \\
\hline $0-99 \ldots$ & 24.5 & 17.0 \\
\hline Credit unions & 45.3 & 28.3 \\
\hline 600 and above & 25.0 & .0 \\
\hline $200-599 \ldots \ldots$ & 27.8 & 11.1 \\
\hline $100-199$ & 30.4 & 13.0 \\
\hline 0-99 & 45.7 & 28.7 \\
\hline
\end{tabular}

NoTE: Percentages based on annualized figures derived from survey data for April 2007. 
electronic checks, while about half of the large ones did, and the proportion declined as size declined from large to small.

An estimated 24 percent of depository institutions reported receiving all interbank check presentments in electronic form. (A depository institution reporting that it received all check presentments electronically may have designated a third-party processor, a correspondent bank, or a Reserve Bank as its presentment point. Given that the probability of receiving a paper check was still high during the survey period, that designee likely received some paper checks, which it forwarded to the customer as electronic images.) None of the largest institutions of any type received all checks in electronic form. Commercial banks and credit unions showed a pattern of increasing proportions of institutions receiving all checks electronically with decreasing size, while for savings institutions there was no clear relationship between size and the proportion receiving all checks electronically.

Credit unions as a group had the highest proportion of institutions receiving at least some interbank checks electronically (45 percent) and the highest proportion receiving all electronically (28 percent). Many credit unions traditionally have provided information about checks paid only as line-item entries on customers' bank statements and likely have faced the fewest obstacles to receiving electronic information in place of paper checks. ${ }^{40}$ The smallest credit unions were more likely to accept some or all checks electronically than larger ones. Smaller institutions, including smaller credit unions, are more likely to use correspondent banks, corporate credit unions, thirdparty processors, or Reserve Banks as their presentment point and to outsource some of the processing, receiving all checks in electronic form. Thus, in some cases the agent designated as the presentment point may have received checks in paper form and sent them to client institutions in electronic form.

While the use of electronic check processing methods was not universal in 2007, comparison with earlier data shows that substantial growth had occurred over a period of one year. Estimates from a survey conducted by the Board in 2006 show that an annualized 2.4 billion checks were presented electronically in March 2006, implying year-to-year

40. Commercial banks and savings institutions, after paying the original canceled checks, have traditionally mailed them to account holders along with their periodic statements. Many depository institutions of all types now offer access to check images on online banking websites and have reduced the mailing of checks to customers. (In 2007, about three-fourths of commercial banks and two-thirds of savings institutions had online banking websites capable of supporting transactions; over half of credit unions did.)
6. Checks deposited and presented electronically through the Reserve Banks, 2005-2008

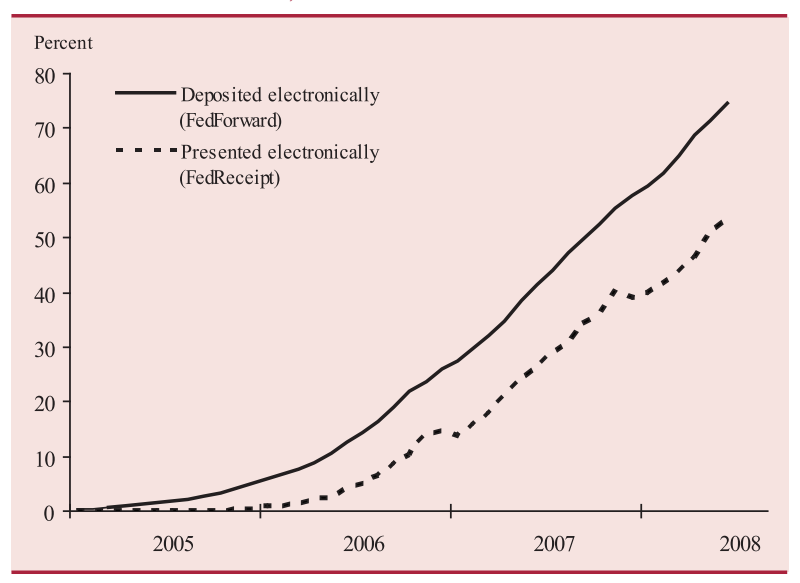

SOURCE: Federal Reserve System Retail Payments Office.

growth of 273 percent. An annualized 1.0 billion substitute checks were presented that same month, implying year-to-year growth of 304 percent. The proportion of depository institutions receiving electronically presented checks also increased substantially; overall, the proportion receiving some checks electronically increased about 10 percentage points and the proportion receiving all electronically, which was relatively low in early 2006, increased about 16 percentage points from 2006 to 2007.

Other data show that electronic presentment of checks processed by the Reserve Banks has increased rapidly. ${ }^{41}$ Presentment of electronic check images to depository institutions by the Reserve Banks, referred to as FedReceipt, was first offered in $2005 .{ }^{42}$ The percentage of FedReceipt checks in all checks presented by the Reserve Banks grew somewhat during the initial months, reaching only 1.44 percent by March of 2006 (chart 6). During March and April 2007, the same time period as the 2007 survey, around 20 percent of checks presented by the Reserve Banks were presented by electronic image, a lower proportion than estimated for interbank checks overall (about 28 percent). The proportion of images in all checks presented by the Reserve Banks was over 53 percent by June 2008, for an annualized growth rate of 119 percent since the 2007 survey, likely reflecting a high overall growth rate for check presentments using electronic images.

41. The Reserve Banks are estimated to have processed 42 percent of all interbank commercial checks processed in the United States in 2006, down from 54 percent in 2003.

42. Reported figures include electronic check images presented using the FedReceipt and FedReceipt Plus products. FedReceipt users, at no charge, received checks as electronic images or as paper, depending on the way the check was deposited and processed. FedReceipt Plus customers received all check presentments as images and paid for imaging those checks that were not deposited as images. 


\section{Electronic Check Deposits}

Some depository institutions have begun to allow check depositors (businesses and even, perhaps, consumers) to truncate checks and make deposits by sending electronic check images (known as "client images") from a remote location rather than by physically depositing the paper checks. During the study period, 1.4 billion checks were deposited as client images (table 6). Another means of check electronification is for a depository institution to image check deposits at special image-capable ATMs, or at the branch at which the check was deposited, and then forward the image on for collection. During the study period, 2.1 billion checks were replaced with such "branch/ATM" images. Collectively, these methods of imaging check deposits remotely are referred to as "remote deposit capture."

Depository institutions can also image checks at their central processing locations, combine them with any images deposited by customers or captured at ATMs or branches, and electronically deposit an electronic bundle of individual check images (known as a cash letter) for collection through a Reserve Bank, private clearinghouse, or third-party processor. The 2007 survey did not collect information on methods used for check collection, and industry-level data are incomplete.

Depository institutions' electronic depositing of check images with the Reserve Banks, through FedForward, began in 2004 (chart 6). During March and April 2007, the same time period as the 2007 study, around 33 percent of checks deposited by Reserve Bank customers were contained in electronic image cash letters. The proportion of checks deposited by electronic image with the Reserve Banks had grown an annualized 93 percent since April 2007, reaching about 74 percent by June 2008 .

The number of checks deposited electronically with the Reserve Banks has always led the number of electronic checks presented, likely reflecting the transition costs to depository institutions before receiving check presentments electronically and the lower prices charged by the Reserve Banks and other intermediaries for electronic check deposits. ${ }^{43}$ Some paying banks may also prefer to receive paper check presentments because they mail canceled paper checks back to account holders along with periodic state-

43. Although prices for electronic check deposits were generally lower than those for paper check deposits, they were higher if substitute checks had to be created because the paying bank required paper.
7. Depository institutions depositing checks electronically, and receiving checks presented electronically, through the Reserve Banks, 2005-2008

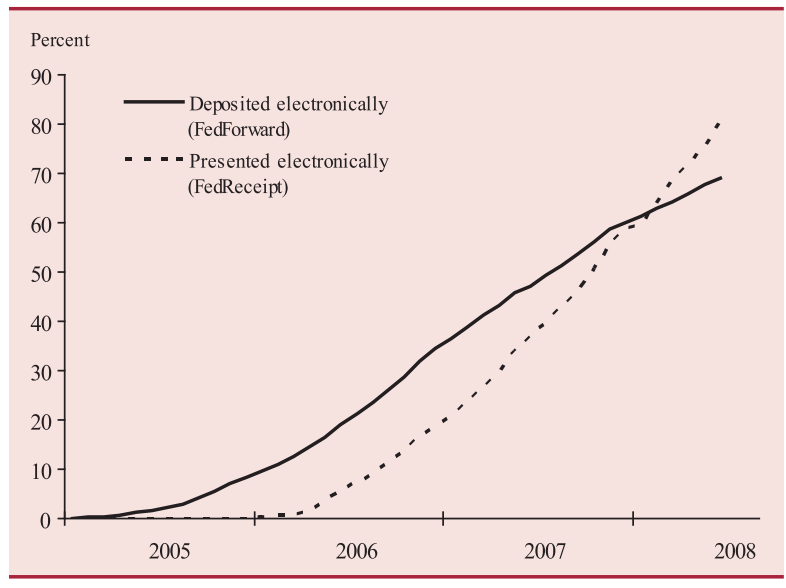

SOURCE: Federal Reserve System Retail Payments Office.

ments. Until February 2008, the proportion of depository institutions depositing electronic check images with the Reserve Banks had exceeded the proportion receiving them (chart 7). In that month the proportions were about equal, and by June 2008 the proportion of depository institutions using FedReceipt reached almost 81 percent, compared with 69 percent using FedForward.

The figures indicate that the check-clearing system is rapidly transitioning to electronic processes and that the variation in adoption by size and type of institution has most likely changed dramatically since March and April 2007.

\section{“On Us" Payments}

Clearing and settlement of on-us paymentspayments that involve only one depository institution-occurs internally at the depository institution, so many of the costs associated with coordinating payments with other depository institutions are not incurred. ${ }^{44}$

Among depository institutions, commercial banks, which typically have business customers, generally had the highest proportion of on-us account debits, by both number and value, while credit unions, which typically do not have business customers, had the lowest (table 9). Most checks involved a business and

44. For checks and ACH, "on us" means that the payer and the payee use the same depository institution. For ATMs, the term means that the withdrawal occurred at a proprietary ATM (an ATM owned by the account holder's depository institution). Data on on-us debit card payments were not collected. On-us account debits plus interbank account debits sum to total payments. 
9. Proportion of selected debits to transaction accounts at depository institutions that were on-us, 2007 Percent

\begin{tabular}{|c|c|c|c|c|c|c|}
\hline \multirow{2}{*}{$\begin{array}{l}\text { Type and size of institution } \\
\text { (transaction deposits in } \\
\text { millions of dollars) }\end{array}$} & \multicolumn{2}{|c|}{ Check payments $^{1}$} & \multicolumn{2}{|c|}{$\mathrm{ACH}$ payments ${ }^{2}$} & \multicolumn{2}{|c|}{ ATM withdrawals } \\
\hline & Number & Value & Number & Value & Number & Value \\
\hline All institutions . & 20.6 & 28.8 & 17.0 & 74.0 & 61.1 & 65.0 \\
\hline Commercial banks & 23.3 & 29.7 & 17.6 & 74.6 & 68.4 & 71.4 \\
\hline $\begin{array}{l}600 \text { and above } \ldots \ldots \ldots \ldots \ldots \\
200-599 \ldots \ldots \ldots \ldots \ldots \ldots \ldots \ldots \\
100-199 \ldots \ldots \ldots \ldots \ldots \ldots \ldots \ldots \ldots \ldots \ldots \\
0-99 \ldots \ldots \ldots \ldots \ldots \ldots \ldots \ldots \ldots\end{array}$ & $\begin{array}{l}21.0 \\
26.4 \\
24.8 \\
29.2\end{array}$ & $\begin{array}{l}28.1 \\
37.4 \\
33.8 \\
33.7\end{array}$ & $\begin{array}{r}20.0 \\
12.2 \\
12.3 \\
3.0\end{array}$ & $\begin{array}{l}76.1 \\
54.4 \\
35.6 \\
12.8\end{array}$ & $\begin{array}{l}69.9 \\
68.0 \\
66.8 \\
58.4\end{array}$ & $\begin{array}{l}73.0 \\
67.6 \\
66.6 \\
60.1\end{array}$ \\
\hline Savings institutions & 12.0 & 19.0 & 28.1 & 60.7 & 62.7 & 65.5 \\
\hline $\begin{array}{l}600 \text { and above . } \\
200-599 \ldots \ldots . \\
100-199 \ldots \ldots \\
0-99 \ldots \ldots \ldots\end{array}$ & $\begin{array}{l}10.9 \\
12.9 \\
12.4 \\
13.3\end{array}$ & $\begin{array}{l}18.2 \\
19.1 \\
19.1 \\
20.4\end{array}$ & $\begin{array}{r}36.1 \\
27.8 \\
12.0 \\
9.3\end{array}$ & $\begin{array}{l}69.3 \\
51.6 \\
38.4 \\
29.5\end{array}$ & $\begin{array}{l}65.4 \\
64.8 \\
59.2 \\
54.3\end{array}$ & $\begin{array}{l}68.7 \\
67.3 \\
61.8 \\
54.2\end{array}$ \\
\hline Credit unions & 3.7 & 6.8 & 1.1 & 1.6 & 37.6 & 40.9 \\
\hline $\begin{array}{l}600 \text { and above } \ldots \ldots \ldots \\
200-599 \ldots \ldots \ldots \ldots \ldots \\
100-199 \ldots \ldots \ldots \ldots \ldots \\
0-99 \ldots \ldots \ldots \ldots \ldots \ldots\end{array}$ & $\begin{array}{l}1.2 \\
4.0 \\
4.1 \\
3.7\end{array}$ & $\begin{array}{l}2.3 \\
7.4 \\
7.1 \\
7.0\end{array}$ & $\begin{array}{r}1.9 \\
1.2 \\
1.8 \\
.9\end{array}$ & $\begin{array}{l}1.6 \\
1.5 \\
1.8 \\
1.5\end{array}$ & $\begin{array}{l}52.4 \\
48.2 \\
44.8 \\
30.8\end{array}$ & $\begin{array}{l}51.7 \\
49.8 \\
47.2 \\
34.9\end{array}$ \\
\hline
\end{tabular}

NotE: Percentages based on annualized figures derived from survey data for March and April 2007. Excludes institutions that had no transaction deposits. The number and value of debits to transaction accounts are revised from figures reported in Federal Reserve System, "The 2007 Federal Reserve Payments Study." See the appendix for details.

a consumer, so banks with both business and consumer customers were more likely to have on-us payments. ${ }^{45}$

Overall, 21 percent of checks paid in 2007 were on-us checks, about 2 percentage points lower than the estimate from the 2004 depository institution survey. The on-us proportion declined overall for commercial banks and increased overall for savings institutions and credit unions. Commercial banks had a higher on-us proportion (23 percent) in 2007 than both savings institutions (12 percent) and credit unions (4 percent). In light of the dramatic growth of check conversion, one possible explanation for increases in the proportion of on-us account debits at all but the largest commercial banks and savings institutions is that smaller proportions of those institutions' on-us checks were eligible-for-conversion consumerto-business checks.

The proportion of on-us ACH payments fell from 20 percent to 17 percent between 2004 and 2007. By value, however, the proportion increased substantially, from 43 percent to 74 percent. For both years, the estimated on-us proportion by value was overstated, apparently because a handful of very large institutions included internal account-balancing and settlement transactions, called offset entries, in their

45. Gerdes and Walton, "The Use of Checks and Other Noncash Payment Instruments."
1. Checks paid, that is, checks that were on-us (involving only one depository institution) and checks processed through the interbank check-clearing system, including original paper checks and truncated checks presented either electronically or as paper substitute checks. Does not include U.S. Treasury checks and U.S. Postal Service money orders.

2. Electronic payments processed through the automated clearinghouse system, including checks converted to electronic payments.

reported $\mathrm{ACH}$ values. The increase in the proportion by value was due to a change in the survey form, which allowed the separate reporting of network and on-us ACH volumes for 2007, leaving the overstatement to affect mainly the on-us amounts. ${ }^{46}$

Excluding the overstated $\mathrm{ACH}$ values, the largest proportions of on-us account debits, by both number and value, were consistently for ATM withdrawals. Most check and $\mathrm{ACH}$ transactions involve payments to other parties, who choose the depository institution in which to deposit funds. In the case of ATM withdrawals, the account holder plays the role of payee and payer, choosing the depository institution in both cases. Not surprisingly, therefore, these account debits are more likely to be on-us. Between 2004 and 2007, the on-us portion of ATM withdrawals overall increased slightly, from less than 60 percent to over 61 percent by number, and from over 62 percent to 65 percent by value. For commercial banks, more than 68 percent of ATM withdrawals

46. Because the 2004 survey form intermingled interbank and on-us figures, institutions that had problems distinguishing offset entries appeared to have overestimated the value of both on-us and interbank ACH. While offset entries continued to appear in the on-us figures for 2007 and apparently have grown substantially larger for a few very large institutions, network value was not as overstated in 2007 as it was in 2004, owing in part to clarification of the survey instrument and to heightened efforts to inform survey respondents through additional communications. 
were on-us in 2007 (71 percent by value). The larger on-us shares for ATM withdrawals also reflect account holder avoidance of the fees commonly charged for using an ATM owned by another depository institution or other company (non-proprietary ATMs). Commercial banks generally have the largest networks of ATMs, making their ATMs more accessible to customers. Even credit unions, which own relatively few ATMs and for which the on-us ratios for checks and $\mathrm{ACH}$ were quite small, as a group had a relatively large on-us share for ATM withdrawals of 38 percent (41 percent by value).

\section{Regional Variation}

Use of debit cards, checks, ACH, and ATM withdrawals differed among the four major regions of the United States defined by the U.S. Census Bureau: Northeast, South, Midwest, and West. Use of these instruments also varied between urban and rural locations.

\section{Variation by Geographic Region}

In 2007, the number of payments by check as a proportion of total account debits ranged from a low of 31 percent in the West to a high of 38 percent in the South (table 10). The proportion of payments by debit card ranged from a low of 33 percent in the Northeast to a high of 42 percent in the West. While the proportion of debit card payments nationwide (36 percent) was greater than the proportion of check payments nationwide (35 percent), by region that relationship held only in the West. ${ }^{47}$ In fact, in the West the number of debit card payments exceeded the number of check payments by almost 37 percent. The proportion of $\mathrm{ACH}$ payments by number ranged from a low of 20 percent in the South to a high of 25 percent in the Northeast. The proportion of ATM withdrawals by number also was lowest in the South, at 6 percent, and highest in the Northeast, at 8 percent.

In terms of value, check payments as a proportion of total account debits ranged from a low of 14 percent in the West to a high of 33 percent in the South. $\mathrm{ACH}$ payments followed the opposite pattern, accounting for a low of 66 percent of total account debits by value in the South and a high of 85 percent in the West. The opposite pattern was due mainly to an especially high average $\mathrm{ACH}$ value in the West.

47. National data for 2006 show that the number of card payments exceeded the number of check payments. However, data on the regional use of credit cards are unavailable, so it is not possible to assess the relative use of cards overall among regions.
(The average $\mathrm{ACH}$ value ranged from a low of $\$ 5,211$ in the South to a high of $\$ 13,381$ in the West.) The average value of check payments ranged from a low of $\$ 1,226$ in the Midwest to a high of $\$ 1,646$ in the Northeast. By contrast, the average value of debit card payments differed little across regions, ranging from a low of $\$ 39$ in the Midwest to a high of $\$ 42$ in the Northeast and West. For ATM withdrawals, the lowest average value was also in the Midwest, at $\$ 95$, and the highest was in the West, at \$104.

Some differences across regions may be due to differences in population size. The number of account debits per capita in 2007 ranged from a low of 252 in the South to a high of 304 in the Northeast (the Midwest, at 303 account debits per capita, was a close second). ${ }^{48}$ For debit card payments, the annual number per capita was highest in the West, at 119, and lowest in the South, at 90. The annual value of debit card payments per capita also was highest in the West, at $\$ 4,987$, and lowest in the South, at $\$ 3,675$. For check payments, the annual number per capita was lowest in the West, at 87, and highest in the Midwest, at 109 . The value of checks per capita was also lowest in the West, but it was highest in the Northeast. For ATM withdrawals, both annual number and annual value per capita were highest in the Northeast and lowest in the South.

Other differences across regions may be due to differences in economic output (defined as the sum of gross state output for the states in the region). To address this possibility, the regions were put on a comparable basis by calculating payment figures in terms of number or value of account debits per $\$ 1,000$ of economic output. The number of account debits per $\$ 1,000$ of regional output in 2007 ranged from a low of 6.0 in the South to a high of 7.3 in the Midwest. The number of checks per $\$ 1,000$ of economic output was lowest in the West, at 1.9 , and highest in the Midwest, at 2.6. The value of checks per $\$ 1,000$ of economic output was also lowest in the West, at $\$ 2,806$, but was highest the Northeast, at $\$ 3,477$.

\section{Urban and Rural Variation}

In 2007, both the total number and the total value of payments were much smaller for rural areas than for urban areas, reflecting the smaller population and

48. Note that per capita figures are based on the entire population and include all payments, not just those made by consumers. Thus, figures do not represent the behavior of adult consumers or heads of household. 
10. Debits to transaction accounts at depository institutions, by geographic region, 2007

\begin{tabular}{|c|c|c|c|c|c|c|c|c|c|c|c|c|c|c|c|}
\hline \multirow[b]{2}{*}{ Item } & \multicolumn{3}{|c|}{ Northeast } & \multicolumn{3}{|c|}{ South } & \multicolumn{3}{|c|}{ Midwest } & \multicolumn{3}{|c|}{ West } & \multicolumn{3}{|c|}{ Total } \\
\hline & $\begin{array}{l}\text { Multi- } \\
\text { region }\end{array}$ & $\begin{array}{l}\text { Single } \\
\text { region }\end{array}$ & $\begin{array}{c}\text { All } \\
\text { insti- } \\
\text { tutions }\end{array}$ & $\begin{array}{l}\text { Multi- } \\
\text { region }\end{array}$ & $\begin{array}{l}\text { Single } \\
\text { region }\end{array}$ & $\begin{array}{c}\text { All } \\
\text { insti- } \\
\text { tutions }\end{array}$ & $\begin{array}{l}\text { Multi- } \\
\text { region }\end{array}$ & $\begin{array}{l}\text { Single } \\
\text { region }\end{array}$ & $\begin{array}{c}\text { All } \\
\text { insti- } \\
\text { tutions }\end{array}$ & $\begin{array}{l}\text { Multi- } \\
\text { region }\end{array}$ & $\begin{array}{l}\text { Single } \\
\text { region }\end{array}$ & $\begin{array}{c}\text { All } \\
\text { insti- } \\
\text { tutions }\end{array}$ & $\begin{array}{l}\text { Multi- } \\
\text { region }\end{array}$ & $\begin{array}{l}\text { Single } \\
\text { region }\end{array}$ & $\begin{array}{c}\text { All } \\
\text { insti- } \\
\text { tutions }\end{array}$ \\
\hline $\begin{array}{l}\text { Number } \\
\text { (billions) }\end{array}$ & 11.0 & 5.5 & 16.6 & 15.7 & 11.8 & 27.5 & 10.5 & 9.6 & 20.0 & 13.7 & 5.9 & 19.5 & 50.9 & 32.8 & 83.6 \\
\hline Check & 3.7 & 2.0 & 5.7 & 5.4 & 5.1 & 10.5 & 3.4 & 3.9 & 7.2 & 4.0 & 2.0 & 6.0 & 16.4 & 12.9 & 29.4 \\
\hline $\mathrm{ACH}$ & 3.0 & 1.2 & 4.1 & 3.4 & 2.1 & 5.5 & 2.9 & 1.6 & 4.5 & 2.9 & 1.0 & 3.9 & 12.2 & 5.9 & 18.1 \\
\hline Debit card & 3.6 & 1.8 & 5.4 & 5.9 & 3.9 & 9.8 & 3.6 & 3.4 & 7.0 & 5.8 & 2.4 & 8.2 & 18.8 & 11.5 & 30.4 \\
\hline ATM .... & .8 & .5 & 1.3 & 1.0 & .7 & 1.7 & .6 & .7 & 1.3 & 1.0 & .4 & 1.4 & 3.4 & 2.4 & 5.8 \\
\hline $\begin{array}{l}\text { Value (trillions } \\
\text { of dollars) } .\end{array}$ & 29.9 & 3.3 & 33.2 & 33.3 & 9.9 & 43.2 & 41.9 & 5.3 & 47.3 & 56.8 & 5.3 & 62.1 & 161.8 & 23.8 & 185.7 \\
\hline Check & 7.7 & 1.7 & 9.4 & 8.9 & 5.2 & 14.1 & 5.8 & 3.1 & 8.9 & 6.5 & 2.3 & 8.8 & 29.0 & 12.2 & 41.2 \\
\hline $\mathrm{ACH}$ & 21.9 & 1.5 & 23.4 & 24.0 & 4.5 & 28.5 & 35.9 & 2.1 & 38.0 & 49.9 & 2.9 & 52.8 & 131.7 & 11.0 & 142.7 \\
\hline Debit card & .2 & .1 & .2 & .2 & .2 & .4 & .1 & .1 & .3 & .2 & .1 & .3 & .8 & .5 & 1.2 \\
\hline ATM $\ldots .$. & .1 & $*$ & .1 & .1 & .1 & .2 & .1 & .1 & .1 & .1 & $*$ & .1 & .4 & .2 & .6 \\
\hline $\begin{array}{c}\text { Distribution } \\
\text { by number } \\
\text { (percent) }\end{array}$ & 100.0 & 100.0 & 100.0 & 100.0 & 100.0 & 100.0 & 100.0 & 100.0 & 100.0 & 100.0 & 100.0 & 100.0 & 100.0 & 100.0 & 100.0 \\
\hline Check & 33.5 & 36.2 & 34.4 & 34.1 & 43.4 & 38.1 & 32.3 & 40.2 & 36.0 & 29.3 & 33.9 & 30.7 & 32.3 & 39.5 & 35.1 \\
\hline $\mathrm{ACH}$ & 26.9 & 21.0 & 24.9 & 21.7 & 17.6 & 19.9 & 27.5 & 17.2 & 22.6 & 21.5 & 17.0 & 20.2 & 24.0 & 17.9 & 21.6 \\
\hline Debit card & 32.3 & 33.0 & 32.6 & 37.7 & 32.9 & 35.6 & 34.2 & 35.5 & 34.8 & 42.1 & 41.6 & 41.9 & 37.0 & 35.2 & 36.3 \\
\hline ATM $\ldots .$. & 7.3 & 9.8 & 8.1 & 6.5 & 6.1 & 6.3 & 6.0 & 7.2 & 6.6 & 7.1 & 7.5 & 7.2 & 6.7 & 7.3 & 7.0 \\
\hline $\begin{array}{c}\text { Distribution } \\
\text { by value } \\
\text { (percent) }\end{array}$ & 100.0 & 100.0 & 100.0 & 100.0 & 100.0 & 100.0 & 100.0 & 100.0 & 100.0 & 100.0 & 100.0 & 100.0 & 100.0 & 100.0 & 100.0 \\
\hline Check & 25.8 & 51.2 & 28.3 & 26.8 & 52.1 & 32.6 & 13.8 & 57.8 & 18.7 & 11.5 & 42.9 & 14.2 & 17.9 & 51.2 & 22.2 \\
\hline $\mathrm{ACH}$ & 73.4 & 45.1 & 70.6 & 72.1 & 45.8 & 66.0 & 85.7 & 38.6 & 80.4 & 87.9 & 54.3 & 85.0 & 81.4 & 46.0 & 76.8 \\
\hline Debit card & .5 & 2.3 & .7 & .7 & 1.6 & .9 & .3 & 2.4 & .6 & .4 & 2.0 & .6 & .5 & 2.0 & .7 \\
\hline ATM & .3 & 1.5 & .4 & .3 & .6 & .4 & .2 & 1.1 & .3 & .2 & .8 & .2 & .2 & .9 & .3 \\
\hline $\begin{array}{c}\text { Number per } \\
\text { capita } \ldots . .\end{array}$ & 202 & 101 & 304 & 144 & 108 & 252 & 158 & 145 & 303 & 198 & 85 & 283 & 170 & 110 & 280 \\
\hline Check & 68 & 37 & 104 & 49 & 47 & 96 & 51 & 58 & 109 & 58 & 29 & 87 & 55 & 43 & 98 \\
\hline $\mathrm{ACH}$ & 54 & 21 & 76 & 31 & 19 & 50 & 43 & 25 & 68 & 43 & 14 & 57 & 41 & 20 & 60 \\
\hline Debit card & 65 & 33 & 99 & 54 & 36 & 90 & 54 & 51 & 106 & 83 & 35 & 119 & 63 & 39 & 102 \\
\hline ATM..... & 15 & 10 & 25 & 9 & 7 & 16 & 10 & 10 & 20 & 14 & 6 & 20 & 11 & 8 & 19 \\
\hline $\begin{array}{l}\text { Value per } \\
\text { capita } \\
\text { (dollars) }\end{array}$ & 546,933 & 60,329 & 607,262 & 305,563 & 91,302 & 396,865 & 634,262 & 80,374 & 714,636 & 821,110 & 76,335 & 897,445 & 541,738 & 79,760 & 621,498 \\
\hline Check & 141,109 & 30,868 & 171,977 & 82,006 & 47,540 & 129,546 & 87,532 & 46,461 & 133,993 & 94,669 & 32,717 & 127,387 & 96,959 & 40,824 & 137,784 \\
\hline $\mathrm{ACH}$ & 401,403 & 27,195 & 428,598 & 220,289 & 41,781 & 262,070 & 543,611 & 31,049 & 574,659 & 721,467 & 41,488 & 762,955 & 440,938 & 36,672 & 477,611 \\
\hline Debit card & 2,808 & 1,381 & 4,190 & 2,252 & 1,423 & 3,675 & 2,130 & 1,968 & 4,098 & 3,454 & 1,532 & 4,987 & 2,605 & 1,561 & 4,166 \\
\hline ATM & 1,612 & 885 & 2,497 & 1,016 & 558 & 1,575 & 990 & 896 & 1,886 & 1,519 & 597 & 2,116 & 1,236 & 702 & 1,937 \\
\hline $\begin{array}{l}\text { Average value } \\
\quad \text { (dollars) } \ldots . . .\end{array}$ & 2,702 & 596 & 2,000 & 2,119 & 844 & 1,573 & 4,013 & 554 & 2,358 & 4,152 & 901 & 3,177 & 3,181 & 727 & 2,220 \\
\hline Check & 2,081 & 842 & 1,646 & 1,667 & 1,013 & 1,348 & 1,717 & 797 & 1,226 & 1,634 & 1,140 & 1,470 & 1,762 & 942 & 1,401 \\
\hline $\mathrm{ACH}$ & 7,379 & 1,279 & 5,665 & 7,045 & 2,197 & 5,211 & 12,516 & 1,245 & 8,405 & 16,933 & 2,879 & 13,381 & 10,804 & 1,864 & 7,896 \\
\hline Debit card & 43 & 41 & 42 & 41 & 40 & 41 & 39 & 38 & 39 & 41 & 43 & 42 & 41 & 40 & 41 \\
\hline ATM .... & 109 & 89 & 101 & 108 & 85 & 98 & 104 & 86 & 95 & 109 & 93 & 104 & 108 & 88 & 100 \\
\hline
\end{tabular}

lower economic output of rural areas (table 11). ${ }^{49}$ Check payments constituted 46 percent of debits to transaction accounts in rural areas and 34 percent in urban areas. In contrast, electronic debits- $\mathrm{ACH}$ and debit card payments and ATM withdrawals-were relatively more common in urban areas. Among electronic debits, the urban-rural difference was greatest for debit card payments, which accounted for 37 percent of account debits in urban areas compared with 31 percent in rural areas.

For all types of account debits, the number and value of payments per capita was higher in urban areas, reflecting greater wealth and business activity. The average value of debit card payments was

49. Note that by definition, rural areas include some suburban areas surrounding cities. roughly the same in urban and rural areas $(\$ 41$ versus $\$ 40)$, but the average value of check payments, $\mathrm{ACH}$ payments, and ATM withdrawals was smaller in rural areas.

\section{Comparison with Earlier Findings}

The annual number of check payments declined in all regions between 2004 and 2007 (data not shown). The most pronounced decline occurred in the Midwest - almost 35 checks per capita. The smallest decline was in the Northeast-over 21 checks per capita. The number of checks declined faster in rural areas over the period, at 10.7 percent a year, than in urban areas, at 5.7 percent a year.

For debit card payments, the largest increase in the annual number per capita was in the Northeast, at 
10.-Continued

\begin{tabular}{|c|c|c|c|c|c|c|c|c|c|c|c|c|c|c|c|}
\hline \multirow[b]{2}{*}{ Item } & \multicolumn{3}{|c|}{ Northeast } & \multicolumn{3}{|c|}{ South } & \multicolumn{3}{|c|}{ Midwest } & \multicolumn{3}{|c|}{ West } & \multicolumn{3}{|c|}{ Total } \\
\hline & $\begin{array}{l}\text { Multi- } \\
\text { region }\end{array}$ & $\begin{array}{l}\text { Single } \\
\text { region }\end{array}$ & $\begin{array}{l}\text { All } \\
\text { insti- } \\
\text { tutions }\end{array}$ & $\begin{array}{l}\text { Multi- } \\
\text { region }\end{array}$ & $\begin{array}{l}\text { Single } \\
\text { region }\end{array}$ & $\begin{array}{l}\text { All } \\
\text { insti- } \\
\text { tutions }\end{array}$ & $\begin{array}{l}\text { Multi- } \\
\text { region }\end{array}$ & $\begin{array}{l}\text { Single } \\
\text { region }\end{array}$ & $\begin{array}{c}\text { All } \\
\text { insti- } \\
\text { tutions }\end{array}$ & $\begin{array}{l}\text { Multi- } \\
\text { region }\end{array}$ & $\begin{array}{l}\text { Single } \\
\text { region }\end{array}$ & $\begin{array}{c}\text { All } \\
\text { insti- } \\
\text { tutions }\end{array}$ & $\begin{array}{l}\text { Multi- } \\
\text { region }\end{array}$ & $\begin{array}{l}\text { Single } \\
\text { region }\end{array}$ & $\begin{array}{l}\text { All } \\
\text { insti- } \\
\text { tutions }\end{array}$ \\
\hline $\begin{array}{c}\text { Number per } \\
\$ 1,000 \text { of } \\
\text { output }^{1} \ldots\end{array}$ & 4.1 & 2.0 & 6.1 & 3.4 & 2.6 & 6.0 & 3.8 & 3.5 & 7.3 & 4.4 & 1.9 & 6.2 & 3.9 & 2.5 & 6.4 \\
\hline $\begin{array}{l}\text { Check } \ldots \ldots \\
\text { ACH } \ldots . . . \\
\text { Debit card } \ldots \\
\text { ATM } \ldots . . .\end{array}$ & $\begin{array}{r}1.4 \\
1.1 \\
1.3 \\
.3\end{array}$ & $\begin{array}{l}.7 \\
.4 \\
.7 \\
.2\end{array}$ & $\begin{array}{r}2.1 \\
1.5 \\
2.0 \\
.5\end{array}$ & $\begin{array}{r}1.2 \\
.7 \\
1.3 \\
.2\end{array}$ & $\begin{array}{r}1.1 \\
.5 \\
.8 \\
.2\end{array}$ & $\begin{array}{r}2.3 \\
1.2 \\
2.1 \\
.4\end{array}$ & $\begin{array}{r}1.2 \\
1.0 \\
1.3 \\
.2\end{array}$ & $\begin{array}{r}1.4 \\
.6 \\
1.2 \\
.3\end{array}$ & $\begin{array}{r}2.6 \\
1.6 \\
2.5 \\
.5\end{array}$ & $\begin{array}{r}1.3 \\
.9 \\
1.8 \\
.3\end{array}$ & $\begin{array}{l}.6 \\
.3 \\
.8 \\
.1\end{array}$ & $\begin{array}{r}1.9 \\
1.3 \\
2.6 \\
.4\end{array}$ & $\begin{array}{r}1.3 \\
.9 \\
1.4 \\
.3\end{array}$ & $\begin{array}{l}1.0 \\
0.4 \\
0.9 \\
0.2\end{array}$ & $\begin{array}{l}2.2 \\
1.4 \\
2.3 \\
0.4\end{array}$ \\
\hline $\begin{array}{l}\text { Value per } \\
\$ 1,000 \text { of } \\
\text { output } \\
\text { (dollars). }\end{array}$ & 11,057 & 1,220 & 12,277 & 7,294 & 2,179 & 9,473 & 15,260 & 1,934 & 17,194 & 18,090 & 1,682 & 19,772 & 12,309 & 1,812 & 14,121 \\
\hline $\begin{array}{l}\text { Check } \ldots \ldots \\
\text { ACH } \ldots \ldots \ldots \\
\text { Debit card } \ldots \\
\text { ATM } \ldots . . .\end{array}$ & $\begin{array}{r}2,853 \\
8,115 \\
57 \\
33\end{array}$ & $\begin{array}{r}624 \\
550 \\
28 \\
18\end{array}$ & $\begin{array}{r}3,477 \\
8,665 \\
85 \\
50\end{array}$ & $\begin{array}{r}1,958 \\
5,258 \\
54 \\
24\end{array}$ & $\begin{array}{r}1,135 \\
997 \\
34 \\
13\end{array}$ & $\begin{array}{r}3,092 \\
6,256 \\
88 \\
38\end{array}$ & $\begin{array}{r}2,106 \\
13,079 \\
51 \\
24\end{array}$ & $\begin{array}{r}1,118 \\
747 \\
47 \\
22\end{array}$ & $\begin{array}{r}3,224 \\
13,826 \\
99 \\
45\end{array}$ & $\begin{array}{r}2,086 \\
15,895 \\
76 \\
33\end{array}$ & $\begin{array}{r}721 \\
914 \\
34 \\
13\end{array}$ & $\begin{array}{r}2,806 \\
16,809 \\
110 \\
47\end{array}$ & $\begin{array}{r}2,203 \\
10,018 \\
59 \\
28\end{array}$ & $\begin{array}{r}928 \\
833 \\
35 \\
16\end{array}$ & $\begin{array}{r}3,131 \\
10,852 \\
95 \\
44\end{array}$ \\
\hline $\begin{array}{c}\text { Number-to- } \\
\text { deposits } \\
\text { ratio }^{2} \ldots\end{array}$ & 95.5 & 96.5 & 95.8 & 127.6 & 72.7 & 96.4 & 124.9 & 81.7 & 99.7 & 124.1 & 79.6 & 106.3 & 117.6 & 79.9 & 99.2 \\
\hline $\begin{array}{l}\text { Check } \ldots \ldots \ldots \\
\text { ACH } \ldots \ldots \ldots \\
\text { Debit card } \ldots . \\
\text { ATM } \ldots \ldots \ldots\end{array}$ & $\begin{array}{r}32.0 \\
25.7 \\
30.9 \\
7.0\end{array}$ & $\begin{array}{r}34.9 \\
20.3 \\
31.8 \\
9.5\end{array}$ & $\begin{array}{r}33.0 \\
23.9 \\
31.2 \\
7.8\end{array}$ & $\begin{array}{r}43.5 \\
27.7 \\
48.1 \\
8.3\end{array}$ & $\begin{array}{r}31.5 \\
12.8 \\
23.9 \\
4.4\end{array}$ & $\begin{array}{r}36.7 \\
19.2 \\
34.4 \\
6.1\end{array}$ & $\begin{array}{r}40.3 \\
34.3 \\
42.8 \\
7.5\end{array}$ & $\begin{array}{r}32.8 \\
14.1 \\
29.0 \\
5.9\end{array}$ & $\begin{array}{r}35.9 \\
22.5 \\
34.7 \\
6.6\end{array}$ & $\begin{array}{r}36.4 \\
26.7 \\
52.2 \\
8.8\end{array}$ & $\begin{array}{r}26.9 \\
13.5 \\
33.1 \\
6.0\end{array}$ & $\begin{array}{r}32.6 \\
21.4 \\
44.6 \\
7.7\end{array}$ & $\begin{array}{r}38.0 \\
28.2 \\
43.5 \\
7.9\end{array}$ & $\begin{array}{r}31.6 \\
14.3 \\
28.1 \\
5.8\end{array}$ & $\begin{array}{r}34.9 \\
21.4 \\
36.0 \\
6.9\end{array}$ \\
\hline $\begin{array}{l}\text { Value-to- } \\
\text { deposits } \\
\text { ratio }^{3} \ldots\end{array}$ & 258,098 & 57,506 & 191,675 & 270,333 & 61,401 & 151,632 & 501,318 & 45,293 & 235,101 & 515,268 & 71,682 & 337,579 & 374,115 & 58,094 & 220,312 \\
\hline $\begin{array}{l}\text { Check } \ldots \ldots \ldots \\
\text { ACH } \ldots \ldots \ldots \\
\text { Debit card } \ldots \ldots \\
\text { ATM } \ldots \ldots \ldots\end{array}$ & $\begin{array}{r}66,590 \\
189,423 \\
1,325 \\
761\end{array}$ & $\begin{array}{r}29,424 \\
25,922 \\
1,317 \\
843\end{array}$ & $\begin{array}{r}54,283 \\
135,282 \\
1,322 \\
788\end{array}$ & $\begin{array}{r}72,551 \\
194,891 \\
1,992 \\
899\end{array}$ & $\begin{array}{r}31,971 \\
28,098 \\
957 \\
376\end{array}$ & $\begin{array}{r}49,496 \\
100,130 \\
1,404 \\
602\end{array}$ & $\begin{array}{r}69,185 \\
429,668 \\
1,684 \\
782\end{array}$ & $\begin{array}{r}26,183 \\
17,497 \\
1,109 \\
505\end{array}$ & $\begin{array}{r}44,081 \\
189,051 \\
1,348 \\
620\end{array}$ & $\begin{array}{r}59,408 \\
452,740 \\
2,168 \\
953\end{array}$ & $\begin{array}{r}30,723 \\
38,959 \\
1,439 \\
561\end{array}$ & $\begin{array}{r}47,917 \\
286,990 \\
1,876 \\
796\end{array}$ & $\begin{array}{r}66,958 \\
304,504 \\
1,799 \\
853\end{array}$ & $\begin{array}{r}29,735 \\
26,711 \\
1,137 \\
511\end{array}$ & $\begin{array}{r}48,842 \\
169,306 \\
1,477 \\
687\end{array}$ \\
\hline 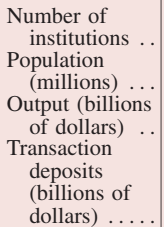 & 1,958 & 162 & $\begin{array}{r}2,120 \\
54.6 \\
2,700\end{array}$ & 4,385 & 265 & $\begin{array}{c}4,650 \\
108.9 \\
4,562\end{array}$ & 4,705 & $\cdots$ & $\begin{array}{r}5,013 \\
66.1 \\
2,749\end{array}$ & 1,859 & 205 & $\begin{array}{r}2,064 \\
69.1 \\
3,138\end{array}$ & $\begin{array}{c}12,907 \\
\ldots \\
\ldots\end{array}$ & $\begin{array}{l}940 \\
\ldots \\
\cdots\end{array}$ & $\begin{array}{r}13,847 \\
299 \\
13,149\end{array}$ \\
\hline
\end{tabular}

NotE: Annualized figures based on survey data for March and April 2007. Multiregion institutions are those that have deposits in more than one region; single-region institutions have deposits in only one region. The Northeast region includes Connecticut, Maine, Massachusetts, New Hampshire, New Jersey, New York, Pennsylvania, Rhode Island, and Vermont. The South region includes Alabama, Arkansas, Delaware, District of Columbia, Florida, Georgia, Kentucky, Louisiana, Maryland, Mississippi, North Carolina, Oklahoma, South Carolina, Tennessee, Texas, Virginia, and West Virginia. The Midwest region includes Illinois, Indiana, Iowa, Kansas, Michigan, Minnesota, Missouri, Nebraska, North Dakota, Ohio, South Dakota, and Wisconsin. The West region includes Alaska, Arizona, California, Colorado, Hawaii, Idaho, Montana, Ne-

47.7 per capita, followed closely by the Midwest, at 46.5 per capita; the smallest increase was in the South, at 31.3 payments per capita, followed by the West, at 39.3 per capita. In 2004, the Northeast had the lowest number of debit card payments per capita; by 2007 that region, at 99 payments per capita, had surpassed the South, at 90 per capita-but both regions remained behind the Midwest, which at 106 payments per capita had come closer to the West, at 119 per capita. The proportion of account debits that were debit card payments increased faster in rural areas, at 14.4 percent a year, than in urban areas, at 11.9 percent a year. vada, New Mexico, Oregon, Utah, Washington, and Wyoming. Component may not sum to totals and may not yield percentages shown because of rounding.

1. Output is measured as the sum of the gross state products in the region.

2. Annual number of debits per $\$ 1,000$ of transaction deposits.

3. Annual value of debits per $\$ 1,000$ of transaction deposits.

* In absolute value, less than 0.05 .

. Not applicable.

SouRCES: Federal Reserve; and U.S. Department of Commerce, Bureau of Economic Analysis and Bureau of the Census.

\section{RETURNED CHECKS AND ACH PAYMENTS}

Some checks that are presented for payment are returned unpaid because of insufficient funds, closed accounts, fraud, or other reasons. The same is true for ACH payments. ${ }^{50}$ Because some payments returned for insufficient funds are presented again ("represented"), and may be returned yet again if funds

50. Credit card and debit card payments may fail because of credit limits or insufficient funds, closed accounts, disputes, or fraud. Because most card payments are approved in real time and are not returned in the same sense as are checks and $\mathrm{ACH}$ payments, they are outside the scope of this discussion. 
11. Debits to transaction accounts at depository institutions, by urban or rural location, 2007

\begin{tabular}{|c|c|c|c|}
\hline Item & Urban & Rural & Total \\
\hline Number (billions) & 72.2 & 11.4 & 83.6 \\
\hline Check & 24.2 & 5.2 & 29.4 \\
\hline $\mathrm{ACH} \ldots$ & 16.0 & 2.0 & 18.0 \\
\hline Debit card & 26.8 & 3.5 & 30.4 \\
\hline ATM.... & 5.2 & .6 & 5.8 \\
\hline Value (trillions of dollars) & 169.3 & 16.2 & 185.5 \\
\hline Check & 36.2 & 4.9 & 41.1 \\
\hline $\mathrm{ACH}$ & 131.4 & 11.1 & 142.6 \\
\hline Debit card & 1.1 & .1 & 1.2 \\
\hline ATM $\ldots . .$. & .5 & .1 & .6 \\
\hline Distribution by number (percent) .. & 100.0 & 100.0 & 100.0 \\
\hline Check & 33.5 & 45.9 & 35.2 \\
\hline $\mathrm{ACH}$ & 22.2 & 17.7 & 21.5 \\
\hline Debit card & 37.2 & 31.0 & 36.3 \\
\hline ATM $\ldots . .$. & 7.2 & 5.4 & 6.9 \\
\hline Distribution by value (percent) & 100.0 & 100.0 & 100.0 \\
\hline Check & 21.4 & 30.1 & 22.2 \\
\hline $\mathrm{ACH}$ & 77.6 & 68.7 & 76.9 \\
\hline Debit card & .7 & .9 & .7 \\
\hline ATM $\ldots . . .$. & .3 & .3 & .3 \\
\hline Number per capita & 298 & 201 & 280 \\
\hline Check & 100 & 92 & 98 \\
\hline $\mathrm{ACH}$ & 66 & 36 & 60 \\
\hline Debit card & 111 & 62 & 102 \\
\hline ATM $\ldots \ldots \ldots \ldots$ & 21 & 11 & 19 \\
\hline Value per capita (dollars) & 699,174 & 286,358 & 620,961 \\
\hline Check & 149,619 & 86,232 & 137,609 \\
\hline $\mathrm{ACH}$. & 542,828 & 196,703 & 477,250 \\
\hline Debit card & 4,563 & 2,468 & 4,166 \\
\hline ATM $\ldots .$. & 2,164 & 955 & 1,935 \\
\hline Average value (dollars) & 2,344 & 1,424 & 2,219 \\
\hline Check & 1,497 & 934 & 1,397 \\
\hline $\mathrm{ACH}$ & 8,215 & 5,532 & 7,915 \\
\hline Debit card & 41 & 40 & 41 \\
\hline ATM $\ldots .$. & 101 & 88 & 100 \\
\hline Number-to-deposits ratio ${ }^{1}$ & 102.4 & 83.0 & 99.2 \\
\hline Check & 34.3 & 38.1 & 34.9 \\
\hline $\mathrm{ACH}$ & 22.7 & 14.7 & 21.4 \\
\hline Debit card & 38.0 & 25.7 & 36.0 \\
\hline ATM $\ldots \ldots$. & 7.4 & 4.5 & 6.9 \\
\hline Value-to-deposits ratio $^{2}$ & 239,919 & 264,263 & 220,122 \\
\hline Check & 51,341 & 35,602 & 48,781 \\
\hline $\mathrm{ACH}$ & 186,269 & 81,210 & 169,179 \\
\hline Debit card & 1,566 & 1,019 & 1,477 \\
\hline ATM $\ldots . .$. & 743 & 394 & 686 \\
\hline Number of institutions & 9,934 & 5,467 & 15,401 \\
\hline Population (millions) . & 242.2 & 56.6 & 298.8 \\
\hline $\begin{array}{l}\text { Transaction deposits } \\
\text { (billions of dollars). }\end{array}$ & 706 & 137 & 843 \\
\hline
\end{tabular}

NOTE: Annualized figures based on survey data for March and April 2007. Excludes institutions that had no transaction deposits. Urban areas are defined as metropolitan statistical areas or New England county metropolitan statistical areas, and rural areas as all other areas. Rural areas include some urbanized areas, such as outlying suburbs that surround metropolitan statistical areas. Components may not sum to totals and may not yield percentages shown because of rounding.

1. Annual number of debits per $\$ 1,000$ of transaction deposits.

2. Annual value of debits per $\$ 1,000$ of transaction deposits.

SOURCES: Federal Reserve; and U.S. Department of Commerce, Bureau of Economic Analysis and Bureau of the Census. are still unavailable, the same returned payments may have been counted more than once. Therefore, the ratio of the number of times a payment, say a check, is returned to the total number of check payments is an upper bound on the probability that a check will be returned.

\section{Returned Checks}

Checks were returned an estimated 187 million times in 2003, compared with 153 million times in 2006. It is estimated that check returns accounted for, at most, 0.51 percent of the estimated total number of checks paid in 2006, or about 5.1 returns for every 1,000 checks paid - about the same proportion as in 2003 compared with about 5.8 returns for every 1,000 checks paid in 2000.

Some checks returned for insufficient funds are re-presented through the ACH system. When such $\mathrm{ACH}$ payments, identified by SEC code as RCK ("re-presented check"), are themselves returned, they are returned through the $\mathrm{ACH}$ system and are no longer identified as check returns. In 2006, about 21 million checks were re-presented through the $\mathrm{ACH}$ system. More than half of these ACH check representments (about 12 million) were themselves returned. The number and value of RCK ACH payments that were returned changed little between 2003 and 2006. The number of returned checks processed through the check collection system (153 million) and the ACH system in 2006 totaled close to 165 million, or 5.5 returns for every 1,000 checks presented, also virtually unchanged since 2003 .

\section{Returned ACH Payments}

About 1.3 percent of retail network $\mathrm{ACH}$ payments were returned in 2006, or 12.7 returns for every 1,000 payments, over twice the rate for checks (table 2). Only about 0.4 percent of large-value CCD (cash concentration or disbursement) transactions were returned, a smaller proportion than for checks or retail $\mathrm{ACH}$ payments. The percentage of retail $\mathrm{ACH}$ payments returned declined from 2003 (when it was 1.5 percent), while the percentage of $\mathrm{CCD}$ transactions returned remained flat. ${ }^{51}$ Most ACH returns in 2006 were PPDs (prearranged payment and deposit entries), by far the largest type of $\mathrm{ACH}$ payment by number, with a rate of 1.1 percent. The second and

51. The 2003 percentages for retail $\mathrm{ACH}$ payments and CCD transactions referred to in this sentence are revised from those reported in Gerdes and others, "Trends in the Use of Payment Instruments," due to a revision to the estimate of total $\mathrm{ACH}$ payments and a change in the method of calculation. 
third most returns were for WEB (web e-check) and TEL (telephone e-check) transactions, which had return rates of 1.5 percent and 6.5 percent, respectively. RCK (re-presented check) payments had the highest return rate, at 58 percent.

After having risen between 2000 and 2003, the return rates for all types of $\mathrm{ACH}$ transactions examined except ACH RCKs declined between 2003 and 2006. The reversal may confirm anecdotal evidence that in response to earlier increases in $\mathrm{ACH}$ fraud, the banking industry stepped up measures to reduce the incidence of fraud and to hold depository institutions more accountable for customer abuse of the $\mathrm{ACH}$ network. The declines suggest that such efforts are having an effect on returns.

\section{SUMMARY AND CONCLUSIONS}

At some point between 2003 and 2006, the number of payments made by credit or debit card in the United States for the first time surpassed the number of checks paid. And also for the first time, the number of debit card payments surpassed the number of credit card payments. Among the major payment types, the greatest percentage increase, by number of payments, was for payments made using the automated clearinghouse system, in part because of a rapid increase in the conversion of checks into electronic ACH payments. The number of checks written continued the decline observed in earlier periods, and the decline accelerated because of $\mathrm{ACH}$ check conversion. By 2006, the number of payments made by electronic means was twice the number of payments made by check.

Later data show that by March and April 2007, the number of debit card payments exceeded the number of check payments. Debit card payments accounted for more than half of all debits to transaction accounts at credit unions, which serve mainly consumer customers, while checks continued to be predominant at commercial banks, which also serve business customers. The number of debit card payments per capita in the Northeast and Midwest regions had begun to catch up to the West, while growth in the South lagged by comparison.

Electronic methods of check clearing are rapidly replacing traditional paper methods. From early 2006 to early 2007, the number of checks presented electronically tripled. The number of substitute checkswhich are created for banks that demand paper after a check has been replaced with an electronic imagealso tripled during the period. The creation of substitute checks allows banks to electronify their processes even if their paying bank counterparties are not ready to do so. In the first quarter of 2007 , about 41 percent of interbank checks were electronified for some part of the check-clearing process ( 28 percent were presented as images, and 13 percent were presented as substitute checks). More recent data show very rapid increases in the proportions of checks presented by and deposited with the Federal Reserve Banks as electronic images.

Implementation of changes that enable the electronic processing of checks requires the commitment and coordination of substantial resources. Depository institutions, third-party processors, and the Reserve Banks have been investing in new technological capabilities to support electronic check processing. Despite the substantial cost of making the transition, electronic processing of checks is moving ahead at a rapid pace.

Changes in payments behavior are due to a number of factors, including technology, preferences, and costs as well as the regulations, policies, and practices that govern the payments system. The recent rapid growth in electronic payments was supported by a very long buildup of technical infrastructure and by spreading acceptance of traditional electronic payment instruments. Legal and regulatory changes have removed significant barriers to the growth of electronic payments. Against this backdrop, rapid changes in the payment system will likely continue through the rest of this decade-and into the next.

\section{APPENDIX: SOURCES OF DATA AND METHODS OF ESTIMATION}

Recent estimates of the number and value of noncash payments came from two surveys conducted in 2007-one of depository institutions (the 2007 depository institution survey) and the other of electronic payment networks, card issuers, and card processors (the 2007 electronic payment survey). Similarly, the estimates for earlier years came from 2004 and 2001 surveys of depository institutions (the 2004 and 2001 depository institution surveys) and electronic payment networks, card issuers, and card processors (the 2004 and 2001 electronic payment surveys). ${ }^{52}$

52. The 2001, 2004, and 2007 surveys were conducted by the Retail Payments Office at the Federal Reserve Bank of Atlanta in collaboration with Board staff. Global Concepts assisted with all three depository institution surveys; in addition, International Communications Research (ICR) assisted with the 2007 and 2004 surveys, and Westat assisted with the 2001 survey. Dove Consulting assisted with all three electronic payment surveys.

The report of the 2007 depository institution survey, "The Depository Institutions Payments Study: A Survey of Depository Institutions for the 2007 Federal Reserve Payments Study" (March 2008), and the report of the 2007 electronic payment survey, "The Electronic Pay- 
The 2004 and 2007 depository institution surveys were similar in most respects. However, the 2007 survey collected additional information on paper and electronic methods of clearing checks. In this article, that additional information is compared with information on methods of clearing checks collected by the Board in a 2006 survey on check losses incurred by, and the funds availability and check-clearing practices of, depository institutions. ${ }^{53}$ The 2001 depository institution survey collected information only about checks and did not collect information about other debits to transaction accounts.

\section{Depository Institution Survey}

\section{Survey Design}

The 2007 depository institution survey collected information from three types of institutions: commercial banks (including agencies and branches of foreign banks); savings institutions (savings banks and savings and loan associations); and credit unions. Information was collected on several types of debits to transaction accounts: checks paid, $\mathrm{ACH}$ payments, debit card payments (both signature-based and PINbased), and ATM withdrawals. (Large-value transfers and teller window withdrawals, which create debits, as well as credit card and currency payments were outside the scope of the survey.)

Depository institutions were asked to report, via questionnaire, the number and dollar value of debits to their accounts, by type of debit, during each of the months March and April 2007. They were also asked to report the number and value of returned checks and, for all debit types except debit card payments, the number and value of on-us debits (debits for which the payee's account and the payer's account are at the same depository institution). As noted earlier, detailed information about methods of check clearing was requested, including number and value of checks presented by form of presentment (paper, either original or substitute, and electronic, either image or MICR line) and number and value of deposited checks (with number of client images and branch/ATM images identified separately).

ments Study: A Survey of Electronic Payments for the 2007 Federal Reserve Payments Study" (March 2008), as well as documents related to the earlier surveys, are available at www.frbservices.org/ communications/payment_system_research.html.

53. The 2006 survey was conducted by the Board for a report to Congress. See Board of Governors of the Federal Reserve System (2007), Report to the Congress on the Check Clearing for the 21st Century Act of 2003 (Washington: Board of Governors, April), www.federalreserve.gov/boarddocs/RptCongress/check21/ check21.pdf.
The population from which the 2007 sample was drawn comprised 13,319 depository institutions (bank subsidiaries of multibank holding companies were treated as a single entity) that reported transaction deposits greater than zero as of September 2006 (June 2006 for credit unions). Based on experience with the 2001 and 2004 depository institution surveys, which had overall response rates higher than 50 percent, a stratified random sample of 2,700 depository institutions was estimated to be needed to produce national estimates of the number and value of debits made via check with a desired precision of at least \pm 5 percent at a 95 percent level of confidence.

For sampling and estimation purposes, depository institutions were separated into four groupscommercial banks; credit unions; and two types of savings institutions, those federally regulated by the Office of Thrift Supervision and those regulated by states. ${ }^{54}$ The largest institutions in each group, as determined by the value of their transaction deposits, and some institutions known to have highly unusual check volumes, such as issuers of rebate checks, were sampled with certainty, meaning that all were included in the sample. The remaining institutions in each group were then stratified by the value of their transaction deposits-eight strata for commercial banks, seven strata for credit unions, and ten strata for savings institutions (five for federally regulated and five for state regulated).

The final sample allocation was determined so as to minimize the approximate standard error of the estimated total number of checks. Because the strata containing the larger depository institutions typically accounted for more paid checks in the 2001 and 2004 samples and had greater variance, they were assigned a larger proportion of the sample. The allocation of the sample between the institution types gave more weight to commercial banks because they were expected to account for a disproportionate share of checks and other account debits, but it also took into account the desirability of producing estimates by depository institution type.

In all, 1,554 commercial banks, 333 savings institutions, and 813 credit unions were included in the sample. Responses were received from 853 commercial banks (including all of the 38 largest), 191 savings institutions (including the 18 largest), and

54. The 2001 and 2004 surveys included a fifth groupdomestically chartered branches of foreign banks. Those institutions had low rates of response and collectively accounted for a very small number and value of payments, and it was determined that they could be excluded from the 2007 survey without a significant loss of information. 
393 credit unions (including the 5 largest), for a total of 1,437 respondents.

By the time survey responses had been received, later data on transaction deposits-data as of March 31, 2007-had become available. Using those later data, the sample and population were restratified to produce estimates for the 13,316 depository institutions that reported transaction deposits greater than zero as of April 30, 2007, the end of the period for which data were collected. The major change resulting from the restratification was an adjustment to the largest size stratum for each depository institution group so that it would be a certainty stratum (that is, all members of the stratum must have responded to the overall survey, although not necessarily to each item). Strata also changed somewhat because of the entry and exit of some institutions between November 2006, when the sample was drawn, and April 2007 , and also because of changes in the value of transaction deposits between September 2006, when transaction deposits used for the sample were reported, and March 2007.

\section{Item Nonresponse and Imputation}

Each respondent was asked to provide four figures (number and value for March and April of 2006) for each item in three questionnaire sections-16 items concerning checks, 9 concerning $\mathrm{ACH}$ payments, and 5 concerning ATM withdrawals and debit card payments-for a total of 120 figures. With 1,437 institutions responding overall, there was a potential for 172,440 completed figures.

Each item included in the survey had logical relationships with other items. For example, groups of subtotals should add up to-or, for incomplete sets, be less than-totals; and number-value pairs should not have a zero amount accompanied by a nonzero amount. In order to use the variety of standard statistical methods that require a rectangular dataset and to make the estimates adhere to logical relationships, missing figures needed to be estimated using a statistical process called imputation. Prior to imputation, responses were checked, and for any violations of identified logical constraints, respondents were contacted and, when appropriate, data edits were made. In most cases in which logical inconsistencies could not be resolved, figures were considered missing and subsequently were imputed.

Of the 1,437 respondents, one-fourth provided all the requested figures, half reported at least 70 percent of the figures, and about two-thirds reported at least 33 percent of the figures. Almost all of the remaining one-third reported only 8 percent or fewer of the requested figures. As a result, some responses were not complete enough to produce reliable imputed figures.

Because some respondents were able to provide reasonable responses for some survey sections but not for others, imputation and estimation was conducted by section. For the checks section to be considered "complete" (that is, eligible for the imputation process), a response was needed for at least one of the four figures for total paid checks. A total of 1,281 responses met this criterion, for a potential of 81,984 figures; of these, 34,597 figures (42 percent) were missing and were imputed. For the $\mathrm{ACH}$ payments section, a response needed to provide at least one figure for number of network or on-us $\mathrm{ACH}$ debits or credits to be considered complete. (A response providing value figures only was not deemed sufficient because some respondents' total $\mathrm{ACH}$ value was known to be overstated due to problems distinguishing $\mathrm{ACH}$ payments from other types of transactions, as reported elsewhere in this appendix.) A total of 1,287 responses met this criterion, for a potential of 46,332 figures; of these, 19,232 figures (42 percent) were missing. For the ATM/debit card section, a response needed to provide at least one number or value for total ATM withdrawals, PIN-based debit card payments, or signature-based debit card payments to be considered complete. A total of 904 responses met this criterion, for a potential of 18,080 figures; of these, 2,146 figures (12 percent) were missing.

For imputation, respondents were grouped by type (commercial bank, savings institution, or credit union) and a matrix of covariances between figures in each section was estimated using a method that produces maximum-likelihood estimates in the presence of missing data through the use of an iterative technique called the EM algorithm. ${ }^{55} \mathrm{~A}$ value was imputed for each missing figure, and after adjustments were made to ensure that logical relationships were not violated, the imputed values produced on the final iteration of the EM algorithm were used for estimation. The imputation model for each missing figure was a linear regression on a related figure from 50 other respondents closest in size as measured by value of transaction deposits. Imputations were performed in a hierarchical fashion, by filling in totals first, followed by subtotals. Independent variables for the regressions were selected by identifying the closest reported

55. For information on the technique, see Roderick J.A. Little and Donald B. Rubin (2002), Statistical Analysis with Missing Data, 2nd ed. (Hoboken, N.J.: Wiley), sections 11.2.1-11.2.2 (pp. 223-25). 
figure in a set of four or, if a subtotal was to be imputed, a total within a logical relationship.

Each fitted regression yielded a predicted value and an associated standard deviation for the missing item. Six datasets containing both actual responses and imputations were created. The first dataset contained imputations that used the predicted, or expected, value only. To arrive at an imputed value for the other five datasets, a random deviate was added to the predicted value, drawn from a normal distribution having a mean of zero and the standard deviation from the fitted regression. This imputation procedure was repeated five times, each time using a newly drawn deviate in the calculation, to create the five additional datasets. All the summary statistics based on the 2007 depository institution survey are estimates calculated from the first dataset. The variation among the estimates calculated using the other five datasets provided information about the uncertainty in the overall estimate arising from the imputations and was used to compute standard errors.

\section{Estimation}

The actual and imputed data for respondents were converted to estimates for the population using a separate ratio estimator for each stratum, with the value of transaction deposits being the covariate for each item. That is, for a given item and within a stratum, the sum of the respondents' data was multiplied by the ratio of the transaction deposits in the population to the transaction deposits at the responding institutions. The associated sampling standard error was based on a classical statistical formula that accounts for the uncertainty arising from the use of a sample rather than a census, and on the variation among imputed figures that accounts for the uncertainty arising from the fact that some items needed to be imputed.

The 95 percent confidence intervals for the national estimate of checks were \pm 1.9 percent of the number of checks paid and \pm 2.3 percent of the value of checks paid. Both confidence interval half-widths were just one-tenth of one percentage point larger than those for the 2004 estimates, despite having used data from fewer respondents $(1,281$ versus 1,501$)$. The confidence intervals for the national estimates of other account debits were generally larger than those for the 2004 depository institution survey.

Estimates by Geographic Region and by Urban or Rural Location of Deposits. Although the survey was not explicitly designed to facilitate geographic analysis of account debit patterns, the responses were sufficient, when combined with external data on each depository institution's total deposits distributed by region, to make broad comparisons possible. For each of four regions-Northeast, South, Midwest, and West-separate estimates were calculated for singleregion depository institutions (those having deposits in only one region) and multiregion depository institutions (those having deposits in more than one region).

The survey did not directly collect regional data from multiregion depository institutions. Information on the distribution of each depository institution's total deposits (transaction plus savings deposits) was available, so each type of account debit for each multiregion depository institution in the population was assumed to be distributed across regions in proportion to the location of the institution's deposits, and its data were allocated to regions accordingly. ${ }^{56}$ Separate estimates were produced for each region using the data from single-region depository institutions and the allocated portion of multiregion depository institutions. New, separate ratio estimators were produced following the procedure described in the preceding section. It turned out that national estimates obtained from aggregating these regional estimates were about the same as those obtained from the original analysis. ${ }^{57}$ For presentation purposes, any difference was proportionally allocated to the regional estimates so that the sums of the regional estimates added up precisely to the national estimates.

The assumption that the payments and transaction deposits of depository institutions are regionally distributed in proportion to the distribution of their total deposits is consistent with the hypothesis that customers of multiregion depository institutions are more similar to each other in their payments behavior, even when they are located in different regions, than they are to customers of different depository institutions. To put it another way, the regional estimates assume that the regional fractions of a depository institution's customers exhibit similar payments behavior. While no better alternative for constructing regional estimates appears to exist given available data, the assumption could affect the accuracy of regional estimates, as the allocation of transaction deposits (or account debits) would be too large (too small) for a region if the actual ratio of total deposits to transac-

56. For credit unions, the geographic distributions of an institution's branches served as a proxy for the geographic distribution of its total deposits.

57. Differences between the sum of regional estimates and the corresponding national estimates did not exceed 1 percent. 
tion deposits (or account debits) for a multiregion institution was higher (lower) in that region.

The uncertainties that arise from allocation of data to regions described above cause difficulties for the statistical analysis of the estimated differences among regions. Sampling standard errors were, therefore, not calculated for the regional estimates. ${ }^{58}$

Estimates of urban and rural debit activity were constructed using a method similar to that used to construct regional estimates. Urban areas were defined as metropolitan statistical areas, and rural areas as all other areas. Thus, some urbanized areas, such as some outlying suburbs that surround metropolitan statistical areas, were included in the rural regions.

\section{Electronic Payment Survey}

For the 2007 electronic payment survey, questionnaires were sent to all 73 well-established electronic payment networks, card issuers, and card processors in order to estimate the number and value of electronic payments originated in the United States in 2006 by means of commonly used payment instruments-general-purpose and private-label credit cards, signature-based and PIN-based debit cards, $\mathrm{ACH}$ payments, and electronic benefits transfers.

Electronic payment networks, card issuers, and card processors can generally supply accurate data on the number and value of the payments they process from business records, and 89 percent of established entities responded with information. Known information on nonrespondents showed that, collectively, the number and value of payments processed by this group were likely very small. An informal method based on publicly available information was used to estimate number and value of payments for nonrespondents; overall, the estimated portion of the total for nonrespondents was 0.2 percent by number and 0.1 percent by value. ${ }^{59}$

Questionnaires were also sent to 33 emerging payments companies that handle online bill payment transactions, RFID transponder-initiated payments, and a variety of other kinds of payments that appear to have potential for growth in the United States, such as person-to-person Internet payments, proprietary cards issued by merchants that can initiate an $\mathrm{ACH}$ payment, mobile payments, and deferred payments. Surveys were returned by 16 companies. Number or

58. For additional details on the regional estimates see Gerdes and others, "Trends in the Use of Payment Instruments."

59. Because of the informal estimation approach, no statistical method of estimating uncertainty was available. Public information about nonrespondents, however, suggests that the number and value of payments they process constitute very small portions of the totals. value of payments for nonrespondents was not estimated, so reported totals for emerging payments are lower bounds for the national totals.

For the 2006 estimates, special efforts were made in estimating the number and value of payments using prepaid cards. A total of 52 prepaid card companies were sent questionnaires, and 38 responded. ${ }^{60} \mathrm{Na}$ tional totals were constructed using respondent information as well as public information about nonrespondents. Nevertheless, the totals for payments by prepaid card are not as reliable as the totals for payments by established types of payments, as the reported portion of totals for prepaid cards was only 58 percent, by both number and value, compared with an overall reported portion for established payments of greater than 99 percent.

\section{Comparison of 2006 and 2007 Estimates}

This article reports estimates of the national number and value of payments in two ways-annualized March and April 2007 estimates of debits from accounts at depository institutions (check, $\mathrm{ACH}$, and debit card payments and ATM withdrawals) and calendar-year 2006 estimates for check, ACH, debit card, and credit card payments, electronic benefits transfers, and ATM withdrawals. The 2007 estimates of account debits are based only on the 2007 depository institution survey, whereas the 2006 estimates for checks and $\mathrm{ACH}$ payments also use information from the 2007 electronic payment survey. The 2006 estimates of debit and credit card payments and EBTs are based solely on the 2007 electronic payment survey. The 2007 estimates of ATM withdrawals from the depository institution survey are used for the 2006 estimates.

Estimates of checks paid in 2007 are for commercial checks only (checks reported by depository institutions), whereas estimates of total checks paid in 2006 are the sum of U.S. Treasury checks, U.S. Postal Service money orders, and commercial checks. The estimates of commercial checks paid for 2006 are adjusted versions of the estimates of commercial checks paid for 2007. The adjustment involved the use of NACHA data showing rapid changes in the number of checks converted per month throughout 2006 and early 2007. As a result, the annualized total number of checks converted in March and April 2007 was an estimated 3.39 billion, compared with 2.61 billion in 2006, a difference of 778 million. The differ-

60. States were also surveyed about the use of prepaid cards for state-provided benefit programs, and 37 states provided information. Payments made with such cards are a subset of total prepaid payments. 
ence in value was $\$ 178$ billion. These differences represent a lower bound estimate (because of the decline in checks) of checks that would have been counted as paid checks if data had been collected during 2006. Based on this argument, the 2006 estimates for commercial checks were calculated as the sums of these differences and the 2007 estimates for commercial checks paid. Based on the same argument, similar adjustments were made for the 2003 estimates of checks paid.

The 2007 electronic payment survey collected information on the number and value of network (interbank) ACH payments. The 2007 depository institution survey collected information on the number and value of network, on-us, and direct (bilaterally exchanged) $\mathrm{ACH}$ payments. Separate proportions of ACH debits and credits by number estimated from the depository institution survey, combined with network ACH debit and credit data from the 2007 electronic payment survey, were used to estimate total on-us ACH payments in 2006. Direct ACH payments were negligible and were included in the on-us figures. The total number of $\mathrm{ACH}$ payments in 2006 was calculated as the sum of these on-us figures and the estimates of the number of network $\mathrm{ACH}$ payments from the 2007 electronic payment study.

The 2007 estimates for the total value of $\mathrm{ACH}$ payments are much higher than the estimates for 2006. Some of the large commercial banks that responded to the depository institution surveys had difficulty distinguishing ACH payments from largevalue funds transfers called offset entries, inflating the value of on-us ACH payments by an unknown amount. ${ }^{61}$ The 2006 estimates of the value of on-us $\mathrm{ACH}$ payments were calculated based on the assumption that the average value of on-us ACH payments is equal to the average value of network $\mathrm{ACH}$ payments. Actual on-us ACH value may be somewhere between the two estimates. These estimates-appropriately adjusted-were used in conjunction with annual 2006 totals provided by electronic payment networks in the electronic payment surveys to estimate the 2006 figures.

For estimates of total $\mathrm{ACH}$, data from the 2007 depository institution survey were used to estimate the fractions of $\mathrm{ACH}$ transactions, by number, that were on-us and cleared in-house (separately for debit and credit transfers). The estimated fractions were applied to 2006 network ACH payment estimates from the electronic payment survey to estimate on-us $\mathrm{ACH}$ payments for 2006. These were added to the network ACH payments in 2006 to yield estimates for total $\mathrm{ACH}$.

61. The difficulty in separating offset entries from $\mathrm{ACH}$ payments was due to the use of a shared platform to process both, a common practice at some of the largest depository institutions. The difficulty, which involves a small number of very large value entries, did not substantially affect the estimates of the number of $\mathrm{ACH}$ payments. 